\title{
Wave-influenced deltas: geomorphological implications for facies reconstruction
}

\author{
JANOK P. BHATTACHARYA* and LIVIU GIOSAN $\dagger$ \\ ${ }^{*}$ Geosciences Department (FO21), University of Texas at Dallas, 2601 North Floyd Road, PO Box 830688, \\ Richardson, TX 75083-0688, USA (E-mail: janokb@utdallas.edu) \\ $\dagger$ Department of Geology and Geophysics, Woods Hole Oceanographic Institution, MS\#22, Woods Hole, \\ MA 02543, USA (E-mail: lgiosan@whoi.edu)
}

\begin{abstract}
A process-based facies model for asymmetric wave-influenced deltas predicts significant river-borne muds with potentially lower quality reservoir facies in prodelta and downdrift areas, and better quality sand in updrift areas. Many ancient barrier-lagoon systems and 'offshore bars' may be better reinterpreted as components of large-scale asymmetric wave-influenced deltaic systems. The proposed model is based on a re-evaluation of several modern examples. An asymmetry index $A$ is defined as the ratio between the net longshore transport rate at the mouth (in $\mathrm{m}^{3}$ year $^{-1}$ ) and river discharge (in $10^{6} \mathrm{~m}^{3} \mathrm{month}^{-1}$ ). Symmetry is favoured in deltas with an index below $\approx 200$ (e.g. Tiber, lobes of the Godavari delta, Rosetta lobe of the Nile, Ebro), whereas deltas with a higher index are asymmetric (e.g. Danube - Sf. Gheorghe lobe, Brazos, Damietta lobe of the Nile). Periodic deflection of the river mouth for significant distances in the downdrift direction occurs in extreme cases of littoral drift dominance (e.g. Mahanadi), resulting in a series of randomly distributed, quasi-parallel series of sand spits and channel fills. Asymmetric deltas show variable proportions of river-, wave- and tide-dominated facies both among and within their lobes. Bayhead deltas, lagoons and barrier islands form naturally in prograding asymmetric deltas and are not necessarily associated with transgressive systems. This complexity underlines the necessity of interpreting ancient depositional systems in a larger palaeogeographic context.
\end{abstract}

Keywords Barrier islands, deltaic sedimentation, littoral drift, reservoir properties, sand bodies, tidal inlets.

\section{INTRODUCTION}

The purpose of this paper is to present a revised process-based model that predicts better the three-dimensional facies architecture of waveinfluenced deltas based on a re-evaluation of several modern examples. Current process-based models for deltaic deposition, developed largely in the 1970s (Broussard, 1975), emphasize variations in the proportions of wave, tide and river influence that are thought to be the primary control on delta morphology and facies architecture (Wright \& Coleman, 1973; Galloway, 1975; Fig. 1). This tripartite classification is still widely used, although more recent work has classified deltas according to other parameters, such as grain size, water depth and feeder type (see reviews by Collela \& Prior, 1990; Bhattacharya \& Walker, 1992; Orton \& Reading, 1993; Suter, 1994; Reading \& Collinson, 1996).

Application of the tripartite model in interpreting ancient delta systems is not without controversy. One serious problem is the general tendency to force-fit particular delta examples into one of the end-member categories or to place complex variable delta systems at a single point on the diagram (e.g. Orton \& Reading, 1993), despite the fact that most deltas are likely to be of mixed influence and plot somewhere within the triangle, as was pointed out by Galloway \& Hobday (1996, p. 102). Errors of interpretation are especially true in subsurface studies, where extrapolation from a few potentially 


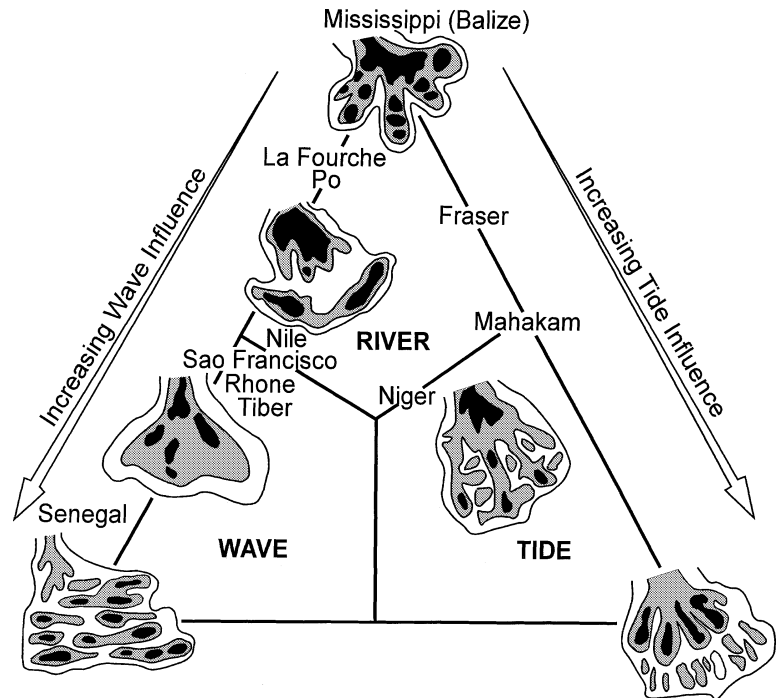

Fig. 1. Sandbody geometries of six basic types of deltas (after Coleman \& Wright, 1975) plotted on the tripartite classification of deltas (Galloway, 1975) as a function of wave, tide and river influences (from Bhattacharya \& Walker, 1992).

unrepresentative sample points is common (Bhattacharya \& Walker, 1992), leading to underor overestimation of facies complexity and reservoir heterogeneity.

The tripartite classification may also be difficult to apply to deltas that show significant differences between different deltaic lobes of the same deltaic system, such as the Danube delta. The Danube delta, deposited onto the north-western margin of the Black Sea, has been described as a wave-influenced, river-dominated delta (Wright \& Coleman, 1973; Galloway, 1975). Although this might be accurate for the whole deltaic edifice, this designation fails to represent the fact that the three active lobes are drastically different morphologically (Diaconu \& Nichiforov, 1963; Giosan, 1998). The northern lobe resembles a river-dominated, shallow-water, Lafourche-type delta, whereas the southern lobes are far more wave dominated. Consequently, facies patterns cannot be predicted if the essentially variable nature of a complex delta is lost when plotted as one point on the delta triangle.

The distinction between wave-dominated deltas and strandplains is also debated; the core issue is the requirement stipulated in the definition of deltas that the sediment must be river derived. Work on Brazilian deltas (e.g. Dominguez, 1996) indicated that significant amounts of sand on the updrift side of a delta are derived laterally from reworked older lowstand shelf sands, and this has led to calls to reclassify these deltas as strandplains. In the case of tide-dominated deltas, there are problems in distinguishing them from tide-dominated estuaries because of a similar inability to identify the dominant sediment source (Bhattacharya \& Walker, 1992; Dalrymple et al., 1992; Willis et al., 1999). This conceptual uncertainty invites several questions. Is the shape of a deposit (bulge) both sufficient and necessary to define a delta or is direct evidence of fluvial input required? What proportions of fluvial deposits are required before the deposit can be considered deltaic?

Another fundamental question is how depositional systems are identified and categorized in the first place. As Galloway \& Hobday (1996, p. 91) pointed out 'few processes or environments are unique to deltaic settings'. This paper will establish that prograding large deltas can contain depositional elements, such as bayhead deltas, lagoons, bays, barrier islands and strandplains, typically associated with non-deltaic depositional systems or destructional phases of deltas. Thus, it is critical to identify the scale of any given depositional element within the broader context of regional stratigraphies.

The main objective of this paper is to address the problem of wave influence on deltas. Do existing deltaic models and classifications explain or predict the variability seen in waveinfluenced systems and, if not, is there a better approach? In order to answer this question, a new mechanistic model is presented for wave-influenced deltas characterized by facies and morphologic asymmetries between the updrift and downdrift sides of a delta. This asymmetric delta model is based on a reinterpretation of the evolution of Sf. Gheorghe lobe of the Danube delta and on published accounts of similar delta lobes. Furthermore, the model is placed into a new perspective by reviewing the present knowledge on the morphology of other wave-influenced deltas and by proposing a new framework for classifying wave-influenced deltas. The implications of the asymmetric delta model for the interpretation of ancient deltaic successions are also discussed. Finally, the influence of this new approach on the general definition of deltas and other paralic depositional systems is evaluated.

\section{ASYMMETRIC WAVE-INFLUENCED DELTAS}

Historically, wave-influenced deltas have been depicted as consisting of a series of straight to 
gently curved, prograding beach ridges, where sand is assumed to be supplied from a nearby river (e.g. Komar, 1973; Coleman \& Wright, 1975; Miall, 1979; Reading \& Collinson, 1996). Preservation of such complexes is thought to result in homogeneous sands formed by accretion of beach and shoreface deposits on either side of the river mouth. One-dimensional models for highly waveinfluenced deltas, such as the São Francisco
(Coleman \& Wright, 1975), and for moderately wave-influenced deltas, such as the Rhone (Oomkens, 1970), showed a sand-dominated coarsening-upward facies succession produced by progradation of a shoreface (Fig. 2). As nondeltaic prograding strandplain systems also produce a similar coarsening-upward facies (see summary by Walker \& Plint, 1992), the recognition of such a succession may not be a valid

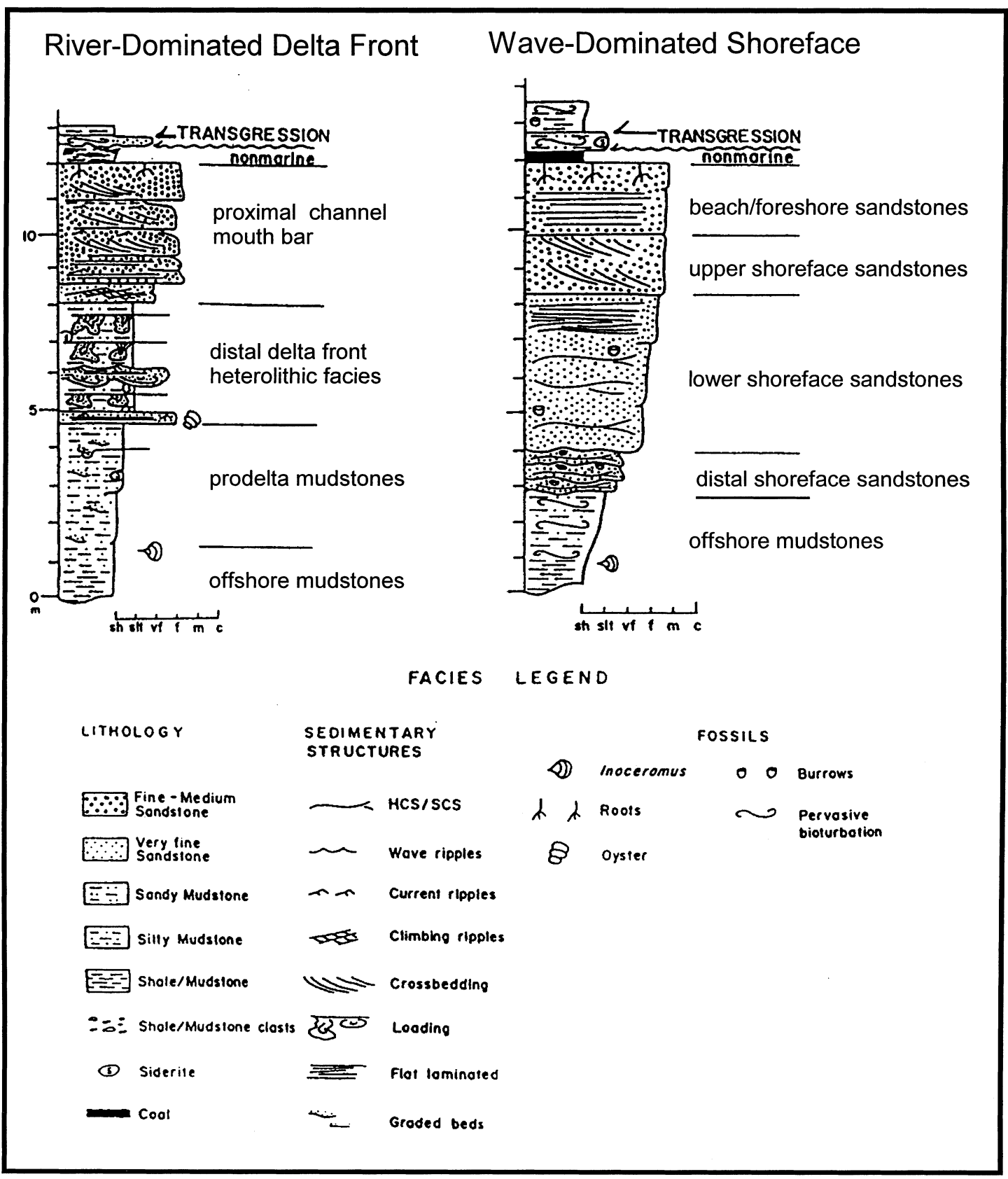

Fig. 2. Comparison of delta front successions in river-dominated vs. wave-dominated deltas (after Bhattacharya \& Walker, 1992). The sandy, wave-dominated shoreface successions would be more typical of the updrift flank of a wave-dominated delta, but could also represent a prograding non-deltaic shoreface. The fluvial-dominated succession is the most irregular and would be typical of bayhead deltas developed within the downdrift flank of a wavedominated delta. 
criterion for interpreting a deposit as uniquely deltaic (Bhattacharya \& Walker, 1992).

In plan view, facies models for deltas emphasize sandbodies that narrow towards a point source (Fig. 1) marked by the feeding river (Coleman \& Wright, 1975; Bhattacharya \& Walker, 1992). Wave-influenced deltas are represented as arcuate to cuspate lobes (Coleman \& Wright, 1975; Weise, 1980; Bhattacharya \& Walker, 1992). More cuspate lobes indicate greater wave influence. One assumption of the above model has been that all the sand is derived directly from the associated river. In these early examples, thicker and more homogeneous sandstones were interpreted as downdrift portions of wave-dominated deltas (Coleman \& Wright, 1975; Weise, 1980; Bhattacharya \& Walker, 1991), although it will be suggested in this paper that the opposite is more likely to be true.

This classic model will be shown to be fairly accurate for examples where net longshore sediment transport is negligible at the river mouth, but it is not applicable to wave-influenced deltas where net longshore transport is high. In the latter case, downdrift deflection of the river mouth (Wright, 1977) has been assumed to be the typical response. An alternative model was suggested by Dominguez (1996): the fluvial effluent behaves like a groyne or barrier (Todd, 1968; Komar, 1973) causing updrift retention of the sediment moving along the coast. As fluvial discharge decreases, there is an intermittent downdrift migration of the river mouth. If the discharge is insufficient to produce a groyne effect, however, the river mouth is deflected entirely downdrift.

\section{Danube delta}

The modern Danube delta has formed by an alternate channel extension process (Wright, 1985): during the Holocene, one to four distributaries have been alternately or contemporaneously active, each building their own lobes (Fig. 3). The delta shows remarkable morphological variability as a result of variation in both riverine discharge among distributaries as well as wave energy along the coast (see review by Giosan et al., 1999). During delta evolution, both riverand wave-influenced lobes have been associated with different distributaries (Panin, 1997). At present, the northernmost distributary (the Chilia) collects $\approx 60 \%$ of the Danube's water and sediment (Bondar et al., 1992). The modern Chilia reached the open sea about 300 years ago (Diaconu \& Nichiforov, 1963), after building two successive river-dominated lacustrine/lagoonal lobes (lobes 4a and 4b; Fig. 3). The high sediment discharge of the Chilia results in rapid progradation across a low-wave-energy, wide and shallow shelf. This environment has favoured successive bifurcations of the 'terminal' distributary channels of the Chilia via middle ground bar formation at the mouths, resulting in the development of a classical lobate, river-dominated delta (lobe $4 \mathrm{c}$ in Fig. 3). Minor wave reworking periodically results in small barrier bars and spits at the mouths of secondary distributaries in the Chilia lobe (Fig. 3). Immediately south of the Chilia lobe, the lower discharge Sulina branch carries about $\approx 20 \%$ of the Danube discharge (Bondar et al., 1992; Fig. 3); the Sulina delta (lobe 2 in Fig. 3) is presently being eroded and destroyed by waves. Starting in the second half of the nineteenth century, the Sulina branch suffered significant engineering interventions (i.e. meander cutoffs, construction of jetties at the mouth, channel dredging) that have affected the natural course of its evolution. The Sf. Gheorghe is the southernmost distributary of the Danube; it has a water and sediment discharge similar in magnitude to that of the Sulina distributary $(\approx 20 \%$ of total Danube discharge) and feeds a distinctly asymmetric, wave-influenced lobe (identified as lobe 3 in Fig. 3). An older lobe built by a palaeo-Sf. Gheorghe distributary is also evident in the morphology of the delta (lobe 1 in Fig. 3; Panin, 1997).

\section{Sf. Gheorghe lobe}

The updrift wing of the modern Sf. Gheorghe lobe consists of a succession of amalgamated beach ridges, known as the Sãrãturile Formation (Fig. 3). Limited ground-penetrating radar (GPR) coverage shows that the ridges are sigmoidal sandy clinoforms, extending to a depth of about $5 \mathrm{~m}$. The downdrift wing is formed by a subparallel series of sandy 'shoestring' ridges encased in delta plain muds (Diaconu \& Nichiforov, 1963; Banu \& Rudescu, 1965). These ridges apparently originated as barrier islands on the river mouth bar (Diaconu \& Nichiforov, 1963). The modern Sacalin (Fig. 3) is the latest generation in this series of barrier islands; it developed from a bar that emerged at the end of the nineteenth century, offshore from the mouth of Sfantu Gheorghe distributary, after an extreme river flood. Over the last 100 years, the island has evolved through elongation and landward roll-over and is now becoming attached to the mainland shore (Giosan, 1998). The Sf. Gheorghe distributary shows three 


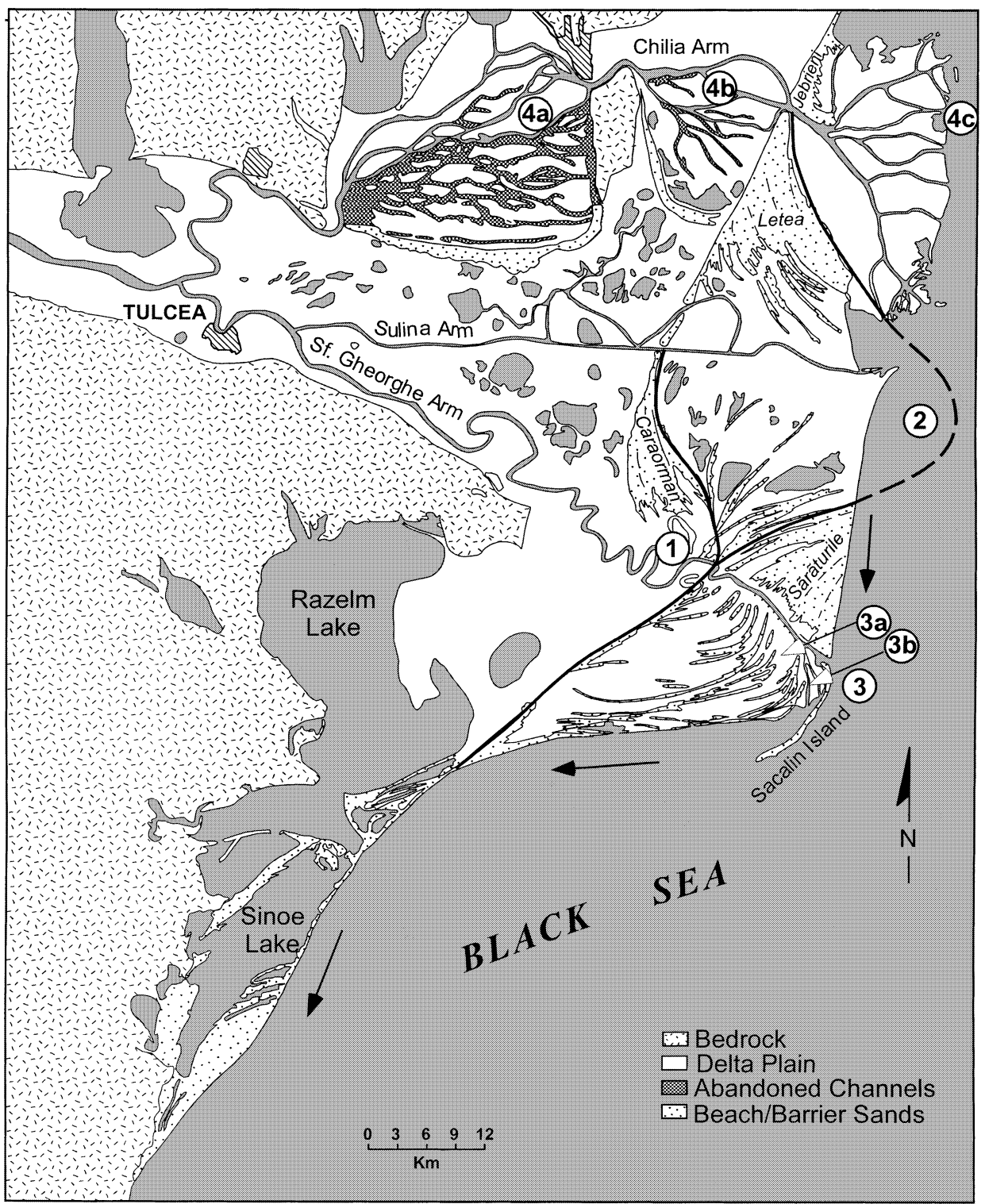

Fig. 3. Modern and relict deltaic lobes of the Danube delta. Longshore drift is directed southward as indicated by black arrows. Asymmetry is preserved in successive lobes: updrift portions consist of massive, sandy beach ridge plains (i.e. the active Sãrãturile Formation - and the relict Caraorman and Letea formations), whereas downdrift portions consist mostly of muds with sparse encased sandy ridges. Note that the northern, highest discharging branch of the Danube river, the Chilia, deposited a river-dominated lobe (4c), whereas the southern branches created wave-dominated lobes ( 2 and 3). The Chilia deposited two successive lacustrine deltas (4a and $4 \mathrm{~b}$ ) before reaching the coast. Lobe 2, the Sulina, is largely inactive and is being reworked. Sands eroded from lobe 2 have been deposited along the updrift flank of the southernmost lobe (3), the Sf. Gheorghe, as Sãrãturile Formation. Two river-dominated, secondary deltas (3a, relict; 3b, still active) are evident in the morphology of the Sf. Gheorghe lobe. An older asymmetric lobe of the Sf. Gheorghe arm (1) is distinguishable in the morphology. The figure is based on a map prepared by Gastescu (1992); outlines of lobes 1 and 2 are after Panin (1989).

main terminal branches, two of them feeding a river-dominated bayhead delta that progrades at a low angle to the general shoreline trend, filling in the shallow backbarrier bay behind the Sacalin barrier (identified as $3 \mathrm{~b}$ in Figs 3 and $4 \mathrm{~A}$ ). An older secondary lobate bayhead delta that also evolved subparallel to the coast is apparent in the morphology of the Sf. Gheorghe lobe (identified as 3a on Figs 3 and 4A). Grain-size analyses show that sands updrift of the Sf. Gheorghe mouth are texturally more mature than the sands downcoast (Giosan, 1993; Romanian Center for Marine Geology \& Geoecology, 1994). As wave energy reaching the coast is significantly higher downcoast of 

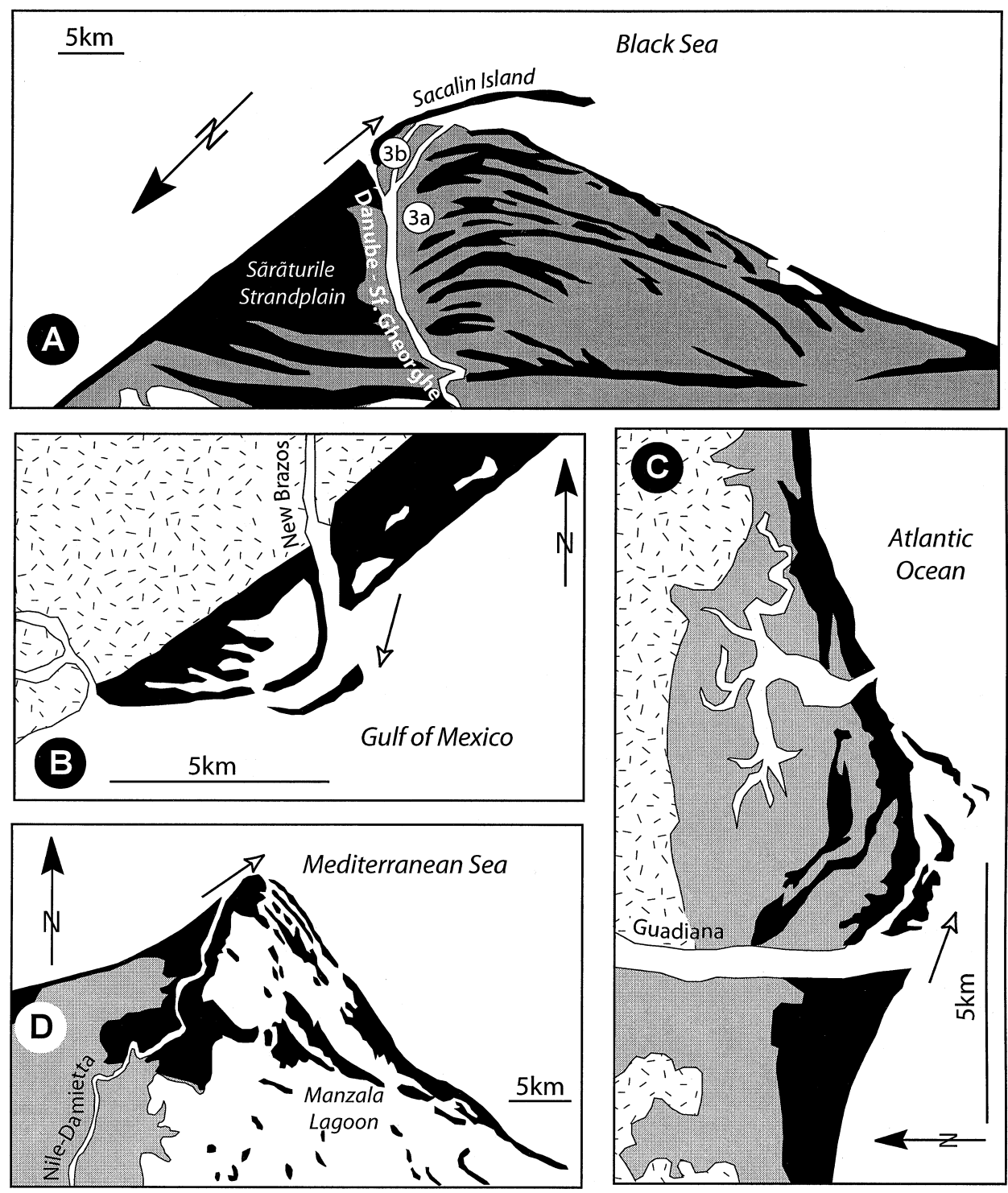

Fig. 4. Morphology of asymmetric deltas/deltaic lobes (sandbodies are coloured in black; deltaic plain features other than sandbodies are coloured in grey; stippled pattern indicates areas that are not part of the modern deltaic complex; longshore drift direction is shown in each case at the river mouth by a white arrow). (A) Sf. Gheorghe lobe of the Danube delta, Romania (after Gastescu, 1992). (B) New Brazos delta, Texas, USA (after Rodriguez et al., 2000). (C) Guadiana delta, Spain/Portugal (after Morales, 1997). (D) Damietta lobe of the Nile delta, Egypt (after Sestini, 1989; Fanos et al., 1993; Benninger et al., 1998). Note the massive sand sheets developing updrift of the river mouths.

the Sf. Gheorghe mouth (Giosan et al., 1999), the southward-decreasing maturity of sediments across the mouth suggests that the updrift Sãrãturile Formation has not received a significant amount of fluvial material from the Sf. Gheorghe distributary but, instead, has been built by reworked sands transported from the erosion of the Sulina lobe further north.

Based on the geomorphology of the Danube deltaic plain (Giosan, 1998) and on the modern evolution (Diaconu \& Nichiforov, 1963; Vespremeanu, 1983; Giosan, 1998; Giosan et al.,
1999), a conceptual model is proposed for the formation of the Sf. Gheorghe lobe. Three phases are recognized: (1) subaqueous delta phase (Fig. 5A) characterized by deposition of sediments primarily on the subaqueous part of the delta; (2) middle-ground bar phase (Fig. 5B), in which a middle-ground bar forms at the mouth, forcing the distributary to bifurcate; and (3) barrier island phase (Fig. 5C) when the emergent linear barrier bars coalesce on the subaqueous delta to form a barrier island that rolls over to the mainland becoming the new shore of the 

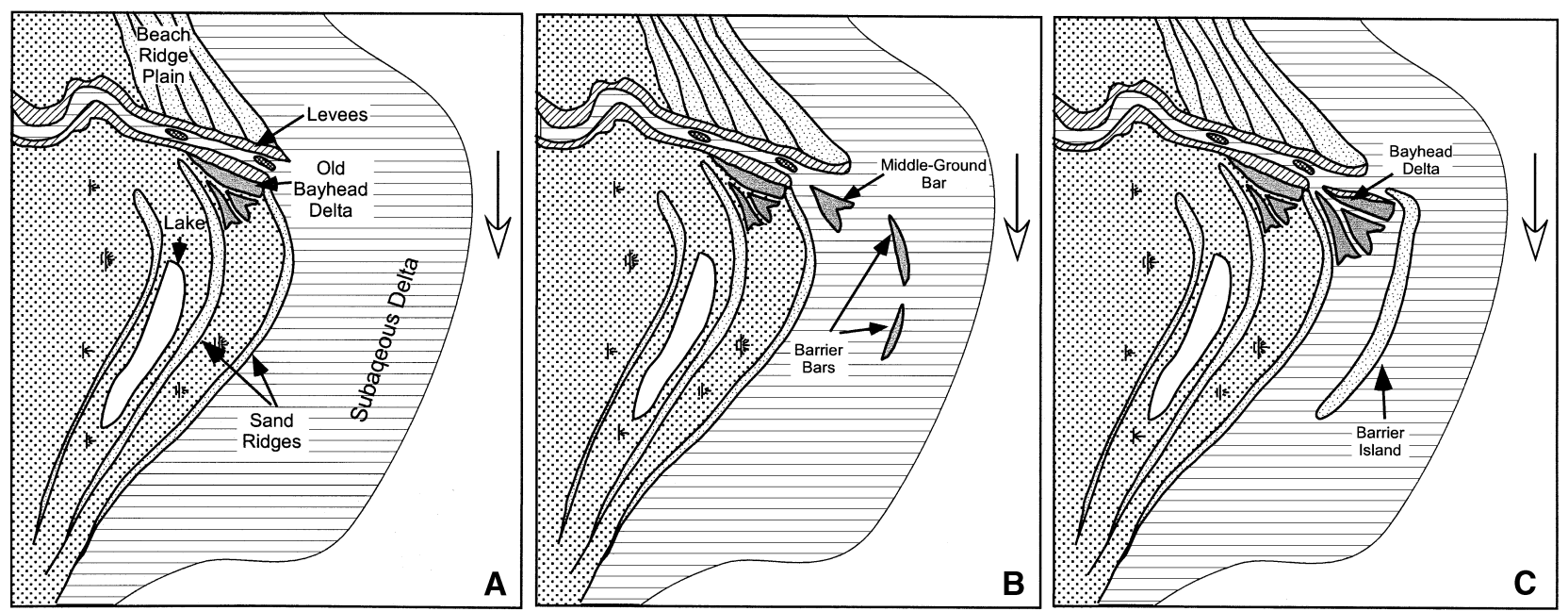

Fig. 5. Conceptual evolution model for the modern Sf. Gheorghe deltaic lobe. (A) Subaquaeous delta phase sediment deposition is primarily on the subaqueous part of the delta; the beach ridge plain on the updrift flank is also advancing. (B) Middle-ground bar phase - a middle-ground bar forms at the mouth, forcing the distributary to bifurcate; linear barrier bars form on the subaqueous delta. (C) Barrier island phase - the linear barrier bars coalesce and become emergent to form a barrier island that rolls over to attach to the mainland; a secondary fluvial-dominated bayhead delta may develop in the sheltered lagoon behind the barrier island. Longshore drift (represented by the white arrow) is southward.

downdrift flank of the delta. A secondary, fluvialdominated bayhead delta may develop in the sheltered lagoon behind the barrier island. Attachment of the barrier to the mainland ultimately creates an elongate lake between them. Thus, a progression from open shelf to protected bay to lake typically occurs.

Since its inception, the asymmetry of the modern Sf. Gheorghe has increased, and the morphology of the lobe indicates that formation of secondary bayhead deltas is a late feature in the evolution style of the lobe. The asymmetric pattern of deltaic evolution can also be recognized in the morphology of other modern or abandoned lobes of the Danube delta plain (Diaconu \& Nichiforov, 1963) during some stage in their evolution. The first deltaic lobe of the Sf. Gheorghe, the Sulina lobe, and even the incipient modern lobe of the Chilia, exhibit beach ridge plains on their northern wings (Fig. 3; Caraorman, Letea and Jebrieni formations respectively).

\section{Brazos delta}

The modern Brazos delta has formed since 1929 when the US Army Corps of Engineers shifted the river course south of the natural mouth at Freeport (Seelig \& Sorensen, 1973). By 1966, a new lobe had already become visible, while the updrift old Brazos delta had been eroding steadily (Seelig \& Sorensen, 1973). Much of the sediments reworked from the older lobe had been transported to the south along the shore and contributed to the formation of the updrift flank of the new delta (Rodriguez et al., 2000). The new lobe exhibits a relatively large, mud-dominated subaqueous delta with its sediments accounting for more than half the entire deltaic edifice (Rodriguez et al., 2000). The morphology and sedimentary composition of the subaerial delta is asymmetric (Fig. 4B). The updrift portion of the new lobe includes a higher proportion of amalgamated beach ridges than the downdrift area where non-amalgamated sandy ridges are separated in a succession by elongate lagoons (Rodriguez et al., 2000). Also, the downdrift ridges are constructed with reworked sand transported to the mouth bar by the river during floods, whereas on the northern side of the mouth, the longshore drift contribution appears to be more important (Rodriguez et al., 2000).

Recent studies of the modern Brazos delta (Hamilton, 1995; Rodriguez et al., 2000) have emphasized the role played by both floods and waves in generating its morphology. Major floods deliver large quantities of sediment to the subaqueous delta. Initially, sand is transported offshore to form an elongate, shore-normal sand body (Hamilton, 1995; Rodriguez et al., 2000). Over the next few months, this sand is rapidly reworked back towards the shoreline to form an emergent, shore-parallel sandy barrier bar 
(Hamilton, 1995; Rodriguez et al., 2000). After each episode of emergence, the bar rolls over onshore while it elongates. In a few years, it becomes the new shoreline by welding to the mainland with its downdrift tip. Fluvio-deltaic and lagoonal muds accumulate continuously in the sheltered environment behind the barrier. These fine-grained deposits are tidally modified and interbedded with sands washed over the bar during storms. Processes associated with barrier bar attachment were examined extensively by Hamilton (1995) and Rodriguez et al. (2000) after the extreme flood of 1992, and similar episodes were inferred by these researchers for floods in 1941, 1957 and 1965. The barrier welding episodes result in the alternating beach ridge sands and mud-filled troughs that characterize the western half of the Brazos delta.

A significant part of the subaqueous delta is developed updrift (east) of the river mouth, although riverine sediment is preferentially transported to the south (Hamilton, 1995; Rodriguez et al., 2000). Prominent subaerial levee spits developed early in the delta progradation on the eastern side of the mouth subnormally to the general direction of the coast (Odem, 1953). Both these phenomena suggest a groyne effect exerted by the Brazos River in blocking the southward sediment drift.

\section{Other asymmetric deltas}

The Guadiana delta, on the Atlantic section of the south-western Iberian Peninsula, displays an asymmetry similar to that shown in the Brazos delta and the Sf. Gheorghe lobe of the Danube delta (Fig. 4C). The western side of the delta is a massive dune-covered sand sheet, whereas the eastern side is composed of old sandy ridges separated by marsh areas. This morphology is a direct result of the interaction between strong sediment drift and the fluvial-estuarine agents (Morales, 1997). At times, an elongated spit develops across the mouth to the east, under the influence of the sand drift from the Algarve coast located to the west (Morales, 1997). Swash bars formed on the subaqueous delta might contribute sand to the spit. Periodically, this spit is cut at the base by the river and isolated as a barrier bar associated with the mouth bar. Barrier bars might be constructed independently by waves by reworking sands delivered to the mouth bar from the estuary via ebb currents (Morales, 1997) and possibly by river floods. These bars could evolve into a larger barrier island in front of the down- drift half of the delta. As noted by Morales (1997), the morphology is atypical for tide-dominated estuaries (Dalrymple et al., 1992), although the tidal range would grant the inclusion of the Guadiana coast in the mixed-energy category (sensu Hayes, 1979). This wave-dominated morphology was attributed by Morales (1997) to the narrow width of the estuary resulting from the inherited morphology of the substrate. Construction of tidal longitudinal sandbodies is inhibited within a narrow estuary, whereas effective flushing of sediment by strong tidal currents provides sand to the open coastal zone where waves could rework them into sandy barriers (Morales, 1997).

The deltaic lobe built by the modern Damietta branch of the Nile is also strongly asymmetric (Fig. 4D). The western side consists of a homogeneous sand sheet formed of sand coarser than the typical Nile beach sands (Coutellier \& Stanley, 1987; Sestini, 1989). To the east of the mouth, a spit complex separates the Manzala lagoon from the Mediterranean. The lagoon has formed in the most actively subsiding area of the Nile delta (Stanley \& Warne, 1998). However, inside the lagoon, there are numerous elongate sandy ridges formed of fine, moderately well-sorted sand (El-Askary \& Lofty, 1980) that represent former strandlines (Sneh \& Weissbrod, 1973; Coutellier \& Stanley, 1987; Sestini, 1989). These beach ridges were probably generated as barrier islands or spits in much the same way as the spit-marsh complex built since 1800 east of the Damietta mouth (Sestini, 1989; Fanos et al., 1991, 1993). The sediment drift at the Damietta mouth is extremely high (i.e. in the order of $400000 \mathrm{~m}^{3}$ year $^{-1}$; Fanos et al., 1991, 1993). Sediment transfer paths across the mouth include the extension and periodic breaking of a subaqueous spit from the west bank and transfer as swash bars (Sestini, 1989).

Prominent wave-influenced asymmetric deltas occur on the Brazilian coast, but their evolution has been much more complex because of a highly variable Holocene sea level (Dominguez, 1996). The São Francisco delta has been used as a type example for a wave-dominated delta (e.g. Wright \& Coleman, 1973; Galloway, 1975; Fig. 6A). However, recent work (Dominguez, 1996) has emphasized that there is clear plan asymmetry in facies. The updrift side of the São Francisco river mouth has evolved as a massive dune-covered sand sheet as a result of a blockage exerted on the updrift longshore drift by the riverine effluent. Recent progradation on the downdrift side involves the formation of barrier islands and spits 

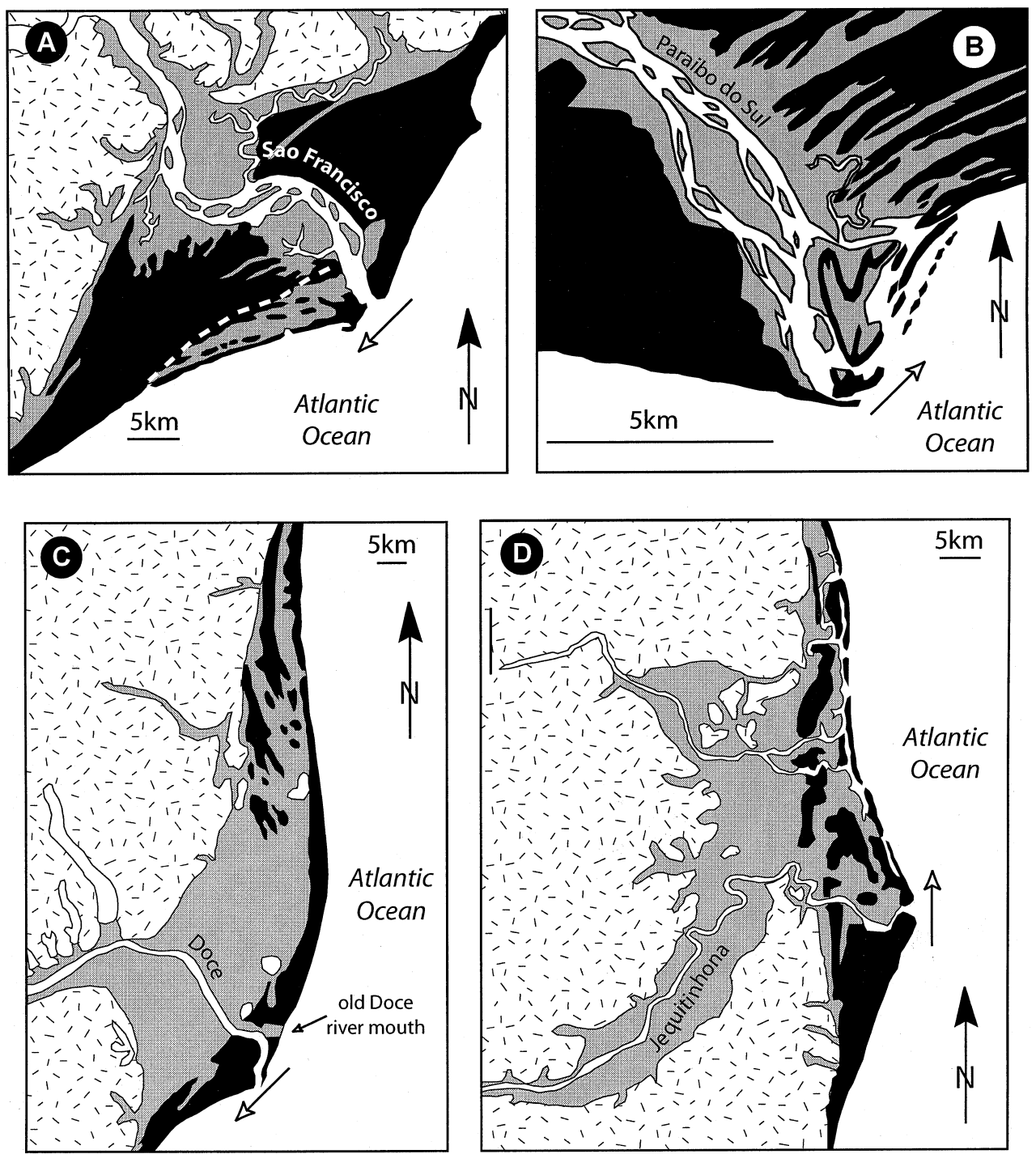

Fig. 6. Morphology of Brazilian deltas (sandbodies are coloured in black; deltaic plain features other than sandbodies are coloured in grey; stippled pattern indicates areas that are not part of the modern deltaic complex; longshore drift direction is shown in each case at the river mouth by a white arrow). (A) Sao Francisco delta. (B) Paraibo do Sul delta. (C) Rio Doce delta. (D) Jequitinhona delta (after Dominguez et al., 1983, 1987; Martin et al., 1987; Dominguez, 1996).

constructed from reworked mouth bar sediments (Dominguez, 1996). These sandy barriers extend along the coast, protecting small lagoons behind that are subsequently filled by fine fluvial sediments and colonized by mangroves (Dominguez, 1996). Sands deposited downdrift have been shown to have lower textural maturity than the more wave-reworked sands in updrift areas (Dominguez et al., 1987; Dominguez, 1996), similar to the Brazos and the Sf. Gheorghe lobe of the Danube. However, an extensive sand sheet developed on the southern half of the delta (Fig. 6A) before the asymmetric pattern was established. This may suggest a change in the development style or it could mean that earlier developed swamps have subsequently been covered by wind-blown sands.

The Paraibo do Sul delta is also asymmetric in morphology (Fig. 6B; Martin et al., 1987). Intensive production of middle-ground bars at the mouth (Fig. 6B) indicates a high sediment discharge. High rates of sediment transfer from west to east, across the river mouth, are suggested by the coexistence of several successive generations of barriers on the downdrift side (east) of the mouth. This strong sediment drift suppresses backbarrier lagoon formation, producing a more amalgamated and sandier beach ridge plain downdrift. 
The Doce and Jequitinhona deltas have shown asymmetric development at some stage in their Holocene history (Fig. 6C and D respectively; Martin et al., 1987). However, modern deltaic lobes of the Rio Doce exhibit more amalgamated beach ridge plains on both sides of the mouth. The strong southward deviation of its course at the mouth appears to be a recent phenomenon.

\section{Asymmetric delta model}

Based on the developmental style of the examined deltas, a conceptual model for the facies architecture of asymmetric deltas can be established (Figs 5 and 7). Strong net longshore sediment transport is one of the main requirements for asymmetric development. The sediment drift is enhanced when the deep-water wave energy flux is strongly skewed to one direction. This situation could occur when oblique waves approach the coast consistently from one direction or when oblique waves from one direction are considerably larger than waves coming from other directions. In these conditions, a relatively steep shelf would promote an even stronger drift by allowing waves to propagate close to the coast without significant shoaling or breaking. An updrift source of sand is also necessary. This could be another active river mouth, older deltaic lobes, other accumulative coastal formations, erosional headlands/cliffs and/or lowstand shelf sands.

The examined cases suggest that asymmetric deltas generally occur in microtidal areas. Riverine discharge should be high enough for most of the year to exert a strong groyne effect in order to block sediment drift. This is crucial in all examined cases to the formation of more or less amalgamated beach ridge plains updrift of the river mouth. Significant sediment input to the mouth bar, usually via extreme floods (e.g. Sf. Gheorghe, Brazos), also seems to be of importance. These floods provide sediments initially deposited on the subaqueous delta that are later reworked into a shore-parallel, sandy barrier bar. Although massive fluvial sediment delivery is responsible for providing the initial sediment to the mouth bar, it is the waves that contribute most to the emergence and formation of a distinctive barrier bar (e.g. Rodriguez et al., 2000). Tidal circulation could also be of importance in redistributing the sediment (e.g. Brazos, Guadiana).

The rate of barrier bar generation and the subsequent evolution of these bars are the result of complex interplay between the various fluvial and marine factors discussed, and examples should be considered on a case-by-case basis. The quasi-cyclicity in bar formation could range in the order of years (e.g. Brazos) to hundreds of years (e.g. Sf. Gheorghe). However, a common characteristic for all examples considered here is the potential of these barriers to create protected lagoonal environments between them and the mainland coast. These lagoons act as sediment traps for fine-grained sediments that would otherwise be reworked by waves. It is possible to have a strong riverine component in the lagoon sedimentation, with the extreme case when a river-dominated, secondary, bayhead delta grows subparallel to the coast (e.g. Sf. Gheorghe). Tidal

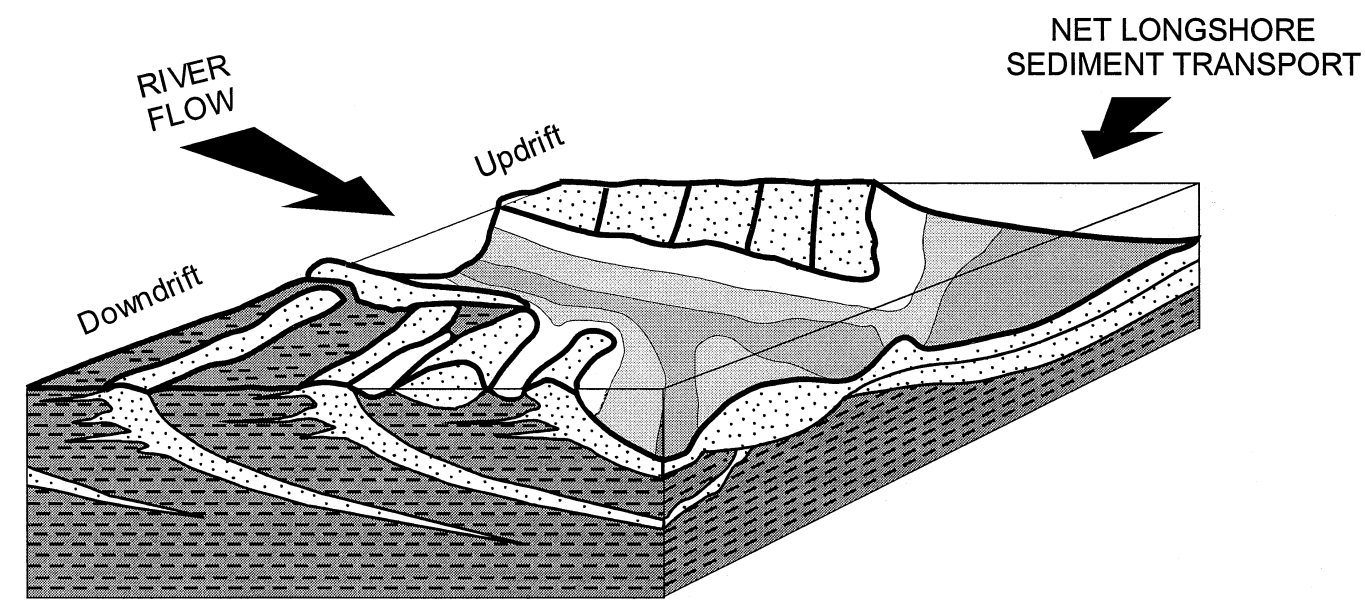

Fig. 7. Block diagram illustrating the inferred three-dimensional facies architecture of an asymmetric delta. Significant prodelta mudstones are associated with the downdrift portion of the delta where sandy barrier bar complexes occur within lagoonal mudstones and bayhead delta deposits. The updrift side of the delta comprises a sandy beach ridge plain. 
currents can affect the transport of sediments into or out of a lagoon. Vegetation might also play a role in sedimentation when marsh and swamps invade the lagoon. If the barrier ultimately attaches to the shore, the former lagoon can be isolated as a lake, if it has not already been filled. The rate of subsidence could play a role in how rapidly the lagoon is filled (e.g. Manzala lagoon). The availability of fine-grained sediment carried by the river (i.e. sediment calibre) could also be important.

When longer time scales are considered, a negative feedback would develop between the morphology of the prograding deltaic lobe and the wave climate at the coast that would affect the developmental style of the lobe itself. Having an increasingly prominent lobe growing relatively perpendicular to the general direction of the adjacent coast would tend to reduce the net sediment drift reaching the mouth, as the dominant waves will approach the updrift side of the delta more and more normally. This is illustrated by the Sulina lobe of the Danube delta, which changed to a more symmetric style of growth in its later evolutionary stage. Autocyclic processes, such as delta or channel switching, could affect the evolution of the delta by increasing or diminishing the water and sediment discharge of a distributary. In the Danube delta, a good example is the increasing dominance of the Sf. Gheorghe distributary over the Sulina in the last 2000 years (Fig. 3). Channel switching and the resulting lobe reworking could also modify the wave climate and therefore the sediment drift reaching the mouth. The gradual destruction of the Sulina lobe, for example, progressively diminished the degree of sheltering provided to the downdrift coast, therefore increasing sediment drift. This contributed to a change in the newly created Sf. Gheorghe lobe towards a more asymmetric evolution style. Allocyclic factors such as sea-level variation could also dramatically affect the evolution of a delta (see review by Bhattacharya \& Walker, 1992), favouring progradation over retrogradation and aggradation or vice versa.

\section{Summary}

Asymmetric deltaic lobes show a difference in facies between the updrift and downdrift areas. The updrift area consists of a beach ridge plain of longshore-derived sand deposited as a result of the groyne effect exerted by the riverine plume. The downdrift side is a succession of elongate sandy ridges separated by mud-filled troughs. A host of modifying processes could be active in deposition of the sediments in the troughs including deposition of secondary bayhead deltas, lagoonal, lacustrine, fluvial, tidal and vegetation-related sedimentation processes. Amalgamation of sand ridges is typical on the updrift side, whereas it is an exception downdrift of the mouth, at least in deltas that have a significant supply of mud to the coastline, which probably represent the large majority of the world's deltas (Orton \& Reading, 1993). The textural maturity of sands is also typically higher on the updrift beach ridge plain than on the downdrift ridges. This challenges the common definition of deltas, in that a significant proportion of the sediment comprising a deltaic edifice could be longshore derived rather than river borne. Inherent in much of the earlier literature is the idea that deltas consist of some proportion of constructional deposits, primary progradational deposits of the river and destructional deposits, such as the wave-reworked barriers described here (e.g. Fisher et al., 1969; Galloway, 1975). Over geological time, significant proportions of river-derived sand can be reworked and recycled into new delta lobes, as described here. Alternatively, other sources of sediment, such as the shelf or non-deltaic formations eroded updrift of the river mouth, can provide sediments in quantities similar to those brought by the river (e.g. Dominguez et al., 1987).

\section{SYMMETRIC WAVE-INFLUENCED DELTAS}

At locations where regional net longshore sediment transport is small, wave-influenced deltas look in plan view more like the classical wavedominated delta model (e.g. Wright \& Coleman, 1973; Bhattacharya \& Walker, 1992; Fig. 8). Deltas assume an arcuate to cuspate planform, with straight or gently curved shorelines. Beach ridges develop on the interdistributary coasts, centred on each distributary mouth. The sandbodies in such a symmetric delta lobe are more or less equally distributed on both sides of the mouth. If there is a weak net sediment drift across the mouth, thicker and more homogeneous sands occur in the downdrift wing (Wright \& Coleman, 1973; Bhattacharya \& Walker, 1992). However, differences in morphology and facies occur as a rule rather than an exception because of the countless variations in both riverine and basinal factors. 

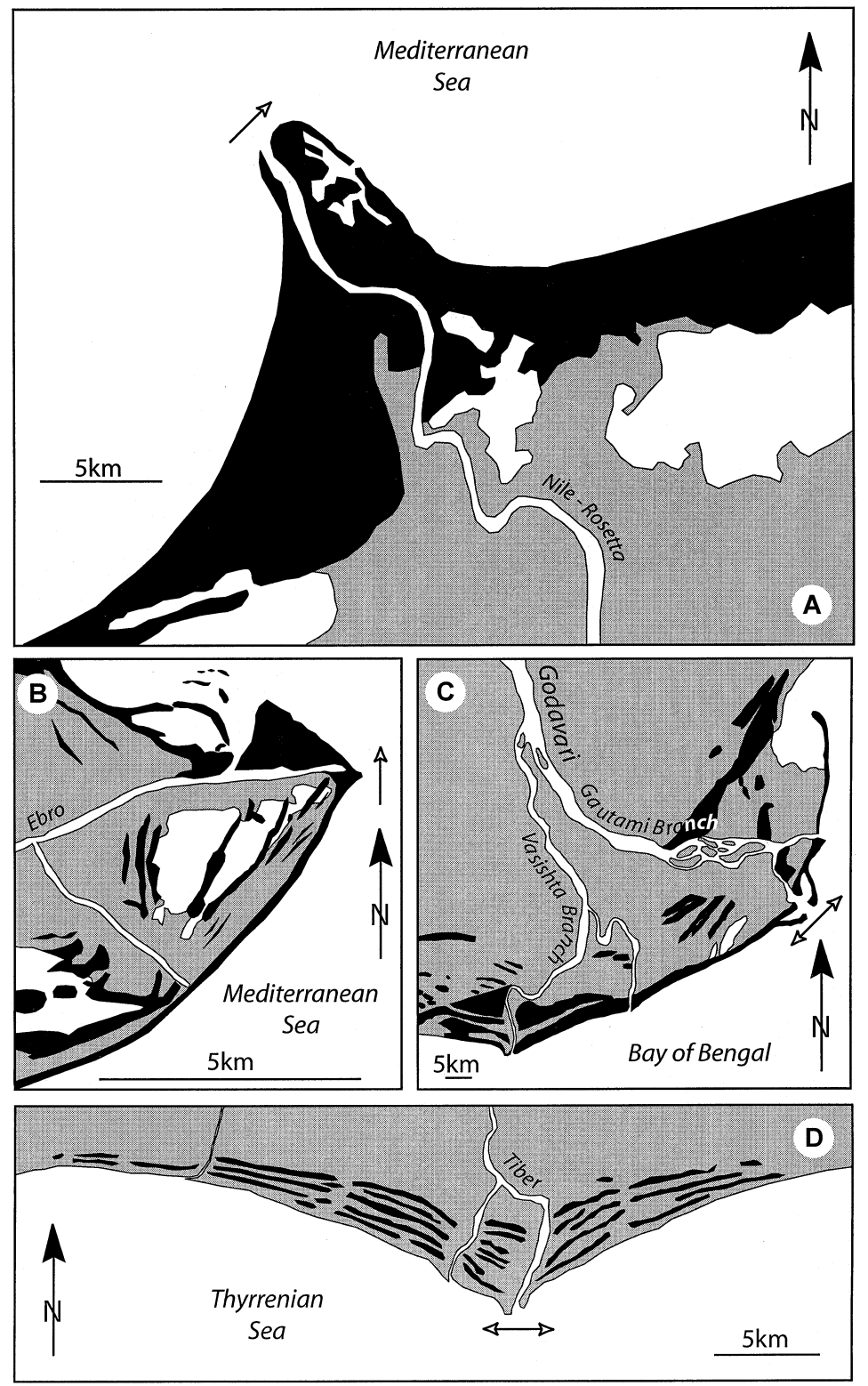

Fig. 8. Morphology of symmetric deltas/deltaic lobes (sandbodies are coloured in black; deltaic plain features other than sandbodies are coloured in grey; stippled pattern indicates areas that are not part of the modern deltaic complex; longshore drift direction is shown in each case at the river mouth by a white arrow). (A) Rosetta lobe of the Nile delta, Egypt (after Sestini, 1989; Fanos et al., 1995). (B) Ebro delta, Spain (after Maldonado, 1975). (C) Godavari delta, India (after Rao \& Vaidyanadhan, 1979; Vaidyanadhan \& Rao, 1979). (D) Tiber delta, Italy (after Bellotti et al., 1994).
The Tiber delta is a good example of a symmetric wave-dominated delta (Fig. 8D; Bellotti et al., 1994). The lower delta plain is characterized by sandy beach ridges, dunes and interdune ponds. The ridges are equally developed both at the exterior side of active distributaries and in the interdistributary area. The main phases of deltaic progradation were probably associated with intensive floods (Bellotti et al., 1994). The fluvial sand and mud delivered by floods is deposited temporarily in front of the mouth, only to be reworked according to grain size towards the coast or offshore (Bortoluzzi et al., 1982; Bellotti et al., 1993).

The morphology of the Vasishta lobe of the Godavari delta (Fig. 8C) on the east coast of India is similar to that of the Tiber delta, with beach ridge plain development on both sides of the distributaries mouths (Vaidyanadhan \& Rao, 1979). The recent evolution of the eastern Gautami lobe of the Godavari delta illustrates how sediment is transferred from the mouth bar towards the distal parts of the delta (Rao \& Vaidyanadhan, 1979). Spits on both sides of the mouth develop from sand reworked as barrier bars from the mouth bar (Rao \& Vaidyanadhan, 1979). Each spit subsequently attaches with its downdrift tip to the mainland as in the case of the Brazos, with the exception that this happens symmetrically on both sides of the mouth.

The Rosetta lobe of the Nile is also symmetric (Fig. 8A), with extensive sand sheets covered 
with dunes on both sides of the mouth (Sestini, 1989). Before the current, human-induced, erosive regime, the Rosetta was a fast-growing lobe characterized by the presence of a middle-ground bar on which barrier bars were formed rapidly and migrated to both sides (Sestini, 1989). Although, at the mouth, there is a strong sediment drift (i.e. $\approx 400000 \mathrm{~m}^{3}$ year $^{-1}$ eastward; Fanos et al., 1991, 1995), this translates into a more modest asymmetry than at the Damietta mouth (Sestini, 1989). Several depressions interspersed with beach ridges occur on the eastern side of the mouth similar to those occurring in asymmetric deltas, but their scale is small relative to the entire area of the downdrift wing. This morphology changes rapidly into a sand sheet further to the east (Sestini, 1989; Chen et al., 1992).

The modern deltaic lobe of the Ebro, on the eastern Mediterranean coast of Spain, is the last example of symmetric wave-influenced deltas considered here (Fig. 8B). Beach ridges are developed extensively on both sides of the modern mouth (Maldonado, 1975) but, in the southern half of the delta, they enclose several lagoons subsequently transformed into shallow lakes. This situation resembles the late evolution of the Sulina lobe of the Danube delta (Fig. 3).

The Rhone delta, also located in the microtidal Mediterranean, has developed symmetric lobes (l'Homer et al., 1981). This is evident in the western part of the delta where well-preserved beach ridges alternate with inter-ridge marshes on both sides of former distributaries (l'Homer et al., 1981); in the eastern part of the delta, the morphology is less visible (l'Homer et al., 1981).

\section{DEFLECTED WAVE-INFLUENCED DELTAS}

It is proposed here that a wave-influenced delta is of a deflected type if the mouth of the river runs subparallel to the coast most of the time during delta evolution. This deflection of the mouth results from the influence of a strong, practically unidirectional longshore component of wave energy at the coast. The distributary is separated from the sea by a sandy spit levee. The type example of such a delta has been the Senegal on the west coast of Africa (Fig. 9A; Wright, 1985). The relatively low discharge of the river over most of the year cannot compete with the strong southward-directed sediment drift. Consequently, sands issuing from the mouth are immediately swept alongshore and remoulded into a barrier spit. When the lower course of the river protected by the spit becomes overextended, the channel loses its gradient advantage and breaches the root of the spit, and the whole process of spit levee formation is reinitiated (Wright, 1985). The spit is probably breached by storms that dictate where the river is going to reconnect to the sea; this might not always happen at the root of the spit (Wright, 1985). The delta thus progrades as a series of randomly distributed, quasi-parallel sand spits and channel fills generally located downdrift of the river course before this course veers downdrift at the coast. Also on the Atlantic coast of Africa, the Saloum delta shows a deflected morphology (Fig. 9B). However, these examples are atypical for deflected deltas, because much of the modern deltas of the Saloum and Senegal were built as bayhead deltas. The bays they grew in were protected by sandy spits formed of sediments eroded from updrift areas (Michel, 1968; Ausseil-Badie et al., 1991). Therefore, these spits were not necessarily deltaic before the bayhead deltas reached the open ocean, and these depositional systems bear more resemblance to the wave-dominated estuaries of Dalrymple et al. (1992).

The Mahanadi delta on the east coast of the Indian subcontinent (Fig. 9C) is much more illustrative because it has not evolved inside a bay (Meijerink, 1982; Bharali et al., 1991; Mohanti, 1993). The random, quasi-parallel distribution of sandy ridges in the deltaic plain (Fig. 9) suggests that deflection of the river mouth was recurrent during development of the Mahanadi delta. During recent times, a string of spits was shed from the Mahanadi mouth towards the north each time the channel resumed a straighter course (Meijerink, 1982).

\section{CLASSIFICATION OF WAVE- INFLUENCED DELTAS}

In 1996, Dominguez noted that 'wave-dominated' deltas (Wright \& Coleman, 1972, 1973; Coleman \& Wright, 1975; Galloway, 1975) had received much less attention than other deltas because of the scarcity of field data at the time that these classifications were formulated. He suggested that the interaction between fluvial discharge and sediment drift might result in a continuum of forms from symmetrical to highly asymmetrical deltas (Dominguez, 1996). This suggestion is expanded here to develop a first-order quantitative classification for wave-influenced deltas. 

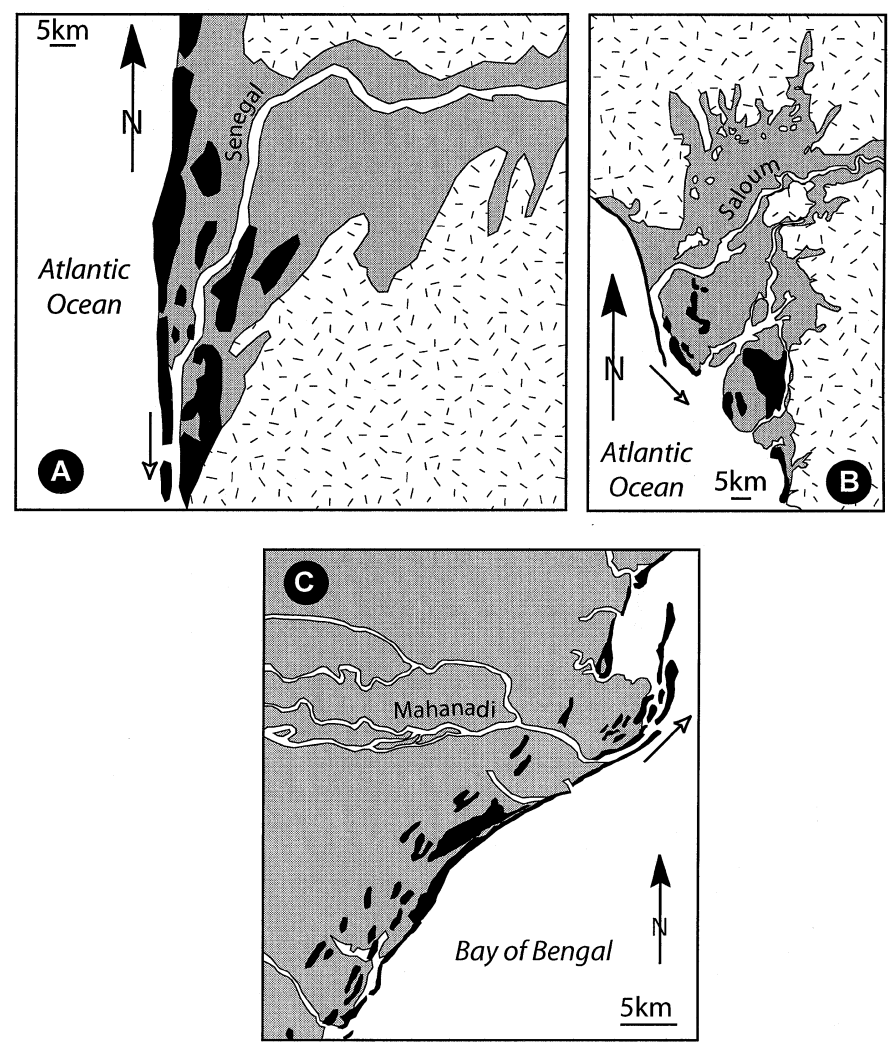

This classification is also based on approaches developed for tidal inlets and associated ebb shoals, small-scale features that share similarities with river deltas (Fig. 10; see reviews by FitzGerald, 1988; US Army Corps of Engineers, 1995).

Tidal currents impose a bidirectional circulation of sediments between the bay and the ocean through an inlet, whereas in the case of river deltas, the dominant flow direction is towards the mouth. FitzGerald (1982) proposed three conceptual models for inlet sediment bypassing on mixed-energy coasts (i.e. coasts affected in significant proportions by both wave and tidal processes; Fig. 10). When inlets are stable, sand moves through the formation, migration and attachment to the shore of large bar complexes (Fig. 10A). Development of bar complexes results from the stacking and coalescing of swash bars on the ebb shoal. Some tidal inlets may bypass sand by breaching the ebb shoal (Fig. 10B). They have a stable inlet throat, but their main channel on the ebb shoal migrates. The dominant direction of longshore sediment transport causes a preferential accumulation of sand on the updrift side of the ebb-tidal shoal, which results in a downdrift deflection of the main ebb channel. When the channel becomes hydraulically inefficient, the inlet will divert its flow to a more direct seaward
Fig. 9. Morphology of deflected deltas (sandbodies are coloured in black; deltaic plain features other than sandbodies are coloured in grey; stippled pattern indicates areas that are not part of the modern deltaic complex; longshore drift direction is shown in each case at the river mouth by a white arrow). (A) Senegal delta, Senegal (after Michel, 1968). (B) Saloum delta, Senegal (after Ausseil-Badie et al., 1991). (C) Mahanadi delta, India (after Meijerink, 1982; Bharali et al., 1991; Mohanti, 1993).

route. In a more extreme case, the sand moves through inlet migration and spit breaching (Fig. 10C). In general, all these processes of sediment transfer described at inlets are easily recognizable in the mouth region of deltaic distributaries. However, they are much less studied than in the case of tidal inlets.

A simple asymmetry index $A$ is proposed for wave-influenced deltas, which expresses the degree of dominance of marine vs. fluvial factors (Table 1 and Fig. 11). This index is similar to the bypassing index for inlets (Bruun \& Gerritsen, 1959) that has been used to describe the relationship between the general morphology and the hydraulics of inlet-ebb shoal systems. The asymmetry index is calculated as the ratio between the net longshore sediment transport rate at the river mouth (expressed in $\mathrm{m}^{3}$ year $^{-1}$ ) and the average water discharge (in million $\mathrm{m}^{3}$ month $^{-1}$ ). Published accounts from a series of deltas or deltaic lobes progressively more asymmetric in morphology and facies were used for these computations. Selection was limited by the fact that there are few estimates of sediment drift at the mouths of modern deltaic distributaries, and they vary widely as a result of the methods used; the most recent and/or most cited values were selected. A direct, first-order correlation between the degree 


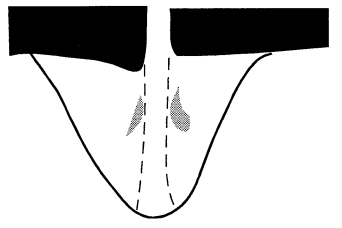

Formation of channel margin bars

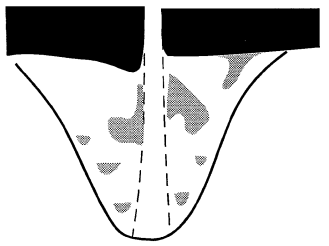

Formation of swash bars, channel margin bar complexes, and subaqueous spits

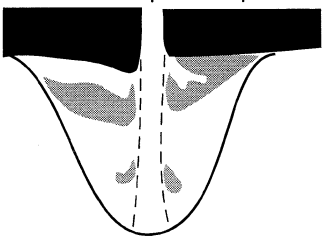

Spit and bar attachments

A

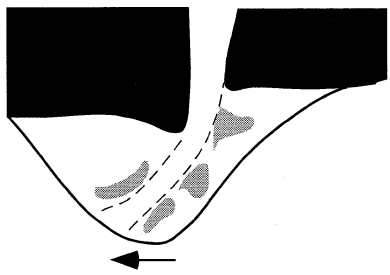

Formation of channel margin bars and spill-over channels

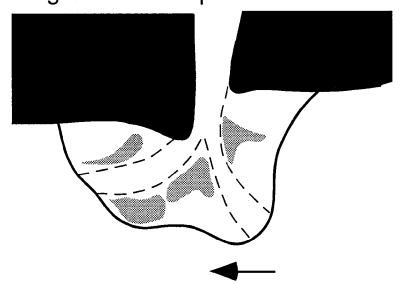

Occupation of a spill-over channe and landward bar migration

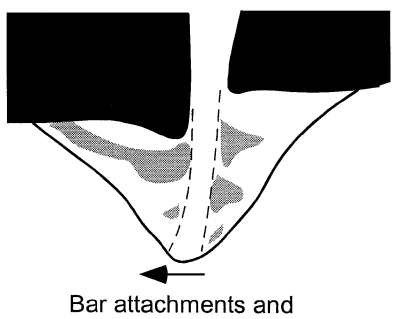

B channel deflection

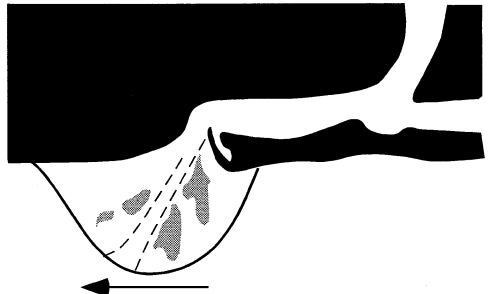

Spit accretion and migration of inlet and ebb-shoal

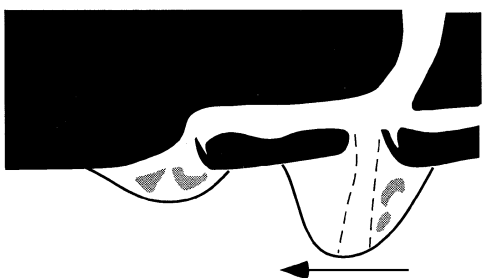

Inlet breaching, formation of new ebb-shoal and destruction of old ebb shoal

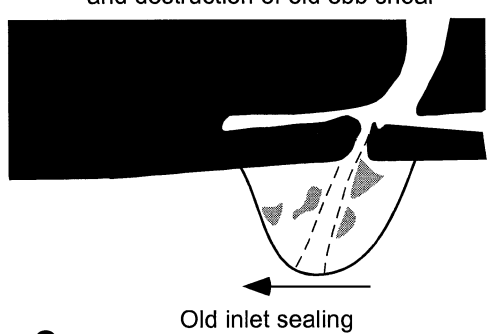

C

Fig. 10. Mechanisms of sediment bypassing at tidal inlets: (A) stable inlet processes; (B) ebb shoal breaching; (C) spit breaching (after FitzGerald, 1982). Barrier islands/spits adjacent to the inlet are in black; submerged sedimentary features are in grey; submerged inlet channels are represented by dashed lines. Relative intensity of regional littoral drift is indicated by arrows.

Table 1. Asymmetry index $(A)$ for a series of wave-influenced deltas/lobes, calculated as the ratio between the net longshore sediment transport rate at the river mouth (expressed in $\mathrm{m}^{3} \mathrm{year}^{-1}$ ) and the average river discharge (in million $\mathrm{m}^{3}$ month $^{-1}$ ).

\begin{tabular}{lclrl}
\hline Delta/lobe & $\begin{array}{l}\text { Discharge } \\
\left(10^{6} \mathrm{~m}^{3} \mathrm{month}^{-1}\right)\end{array}$ & $\begin{array}{l}\text { Sediment drift } \\
\left(\mathrm{m}^{3} \mathrm{year}^{-1}\right)\end{array}$ & $A$ & References \\
\hline Danube/Chilia & 10000 & $\approx 500000$ & 50 & Giosan et al. (1999) \\
Ebro & 1310 & $\approx 100000$ & 76 & Jimenez \& Sanchez-Arcilla (1993) \\
Nile/Rosetta & 2700 & $\approx 400000$ & 148 & Fanos et al. (1995) \\
Nile/Damietta & 1460 & $\approx 400000$ & 274 & Fanos et al. (1993) \\
Danube/Sf. Gheorghe & 3180 & $\approx 1200000$ & 377 & Giosan et al. (1999) \\
Mahanadi & 4080 & $\approx 850000$ & 209 & Mohanti (1993); Meijerink (1982) \\
Senegal & 2280 & $\approx 750000$ & 329 & Barusseau et al. (1995); \\
& & & & Wright \& Coleman (1973) \\
\hline
\end{tabular}

of morphological asymmetry of these deltas and the $A$ coefficient is evident (Table 1, Fig. 11). In the case of the Chilia lobe, where the river dictates the morphology, the coefficient is smallest. For symmetric wave-influenced deltas, the coefficient stays below 200, whereas for the asymmetric deltas, it is over 200 . The asymmetry index for the deflected deltas of the Mahanadi and Senegal is also high ( $>200$ ), but less than one would expect for such extreme cases. This discrepancy suggests that additional factors influence deltaic morphology, such as river sediment discharge, flood frequency or the degree of overlap between the annual maximum sediment discharge and the period of maximum storminess. Moreover, the causal interpretation of the 


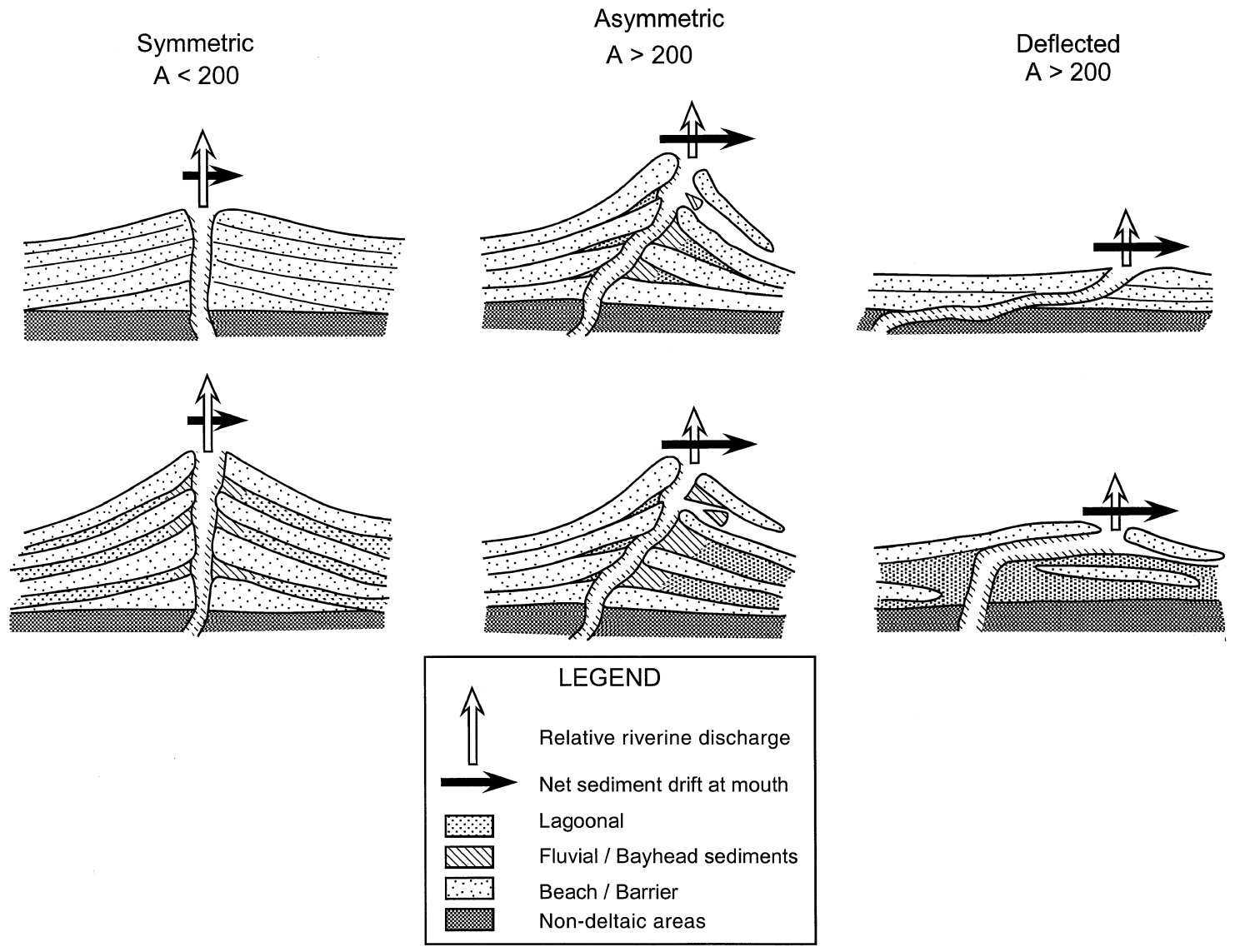

Fig. 11. Process diagram for wave-influenced deltas. Generalized delta morphologies corresponding to different values of the asymmetry index are shown. The upper row includes deltas preserving a lower proportion of fluvially derived mud, whereas the bottom row represents examples of deltas comprising more heterolithic deposits. The ultimate proportion of sand relative to fine sediments in a wave-influenced delta may be affected by factors other than those considered explicitly in the asymmetry index, such as sediment calibre or flood frequency, which could translate into variations in the morphology of the symmetric, asymmetric and deflected wave-influenced deltas.

mud:sand ratio in a wave-influenced delta is much more complex than simply discharge of mud vs. sand and can be controlled by factors such as variations in flood regime or differences in total load.

Overall, the asymmetry index provides a simple physical basis for distinguishing between symmetric and asymmetric/deflected wave-influenced deltas, with the degree of asymmetry growing as the sediment drift at the distributary mouth grows relative to its average discharge. Work is under way to evaluate the index for a larger series of deltas, in compatible conditions, using similar techniques for computing the sediment drift and taking into account other potentially important factors. Further field work in modern deltas is also needed to quantify the sensitivity of trapping mud to short-term vs. long-term events and recurring vs. episodic phenomena, and to understand the mechanisms of sediment transfer at deltaic river mouths in general and in wave-dominated settings in particular. The existing data suggest a direct relationship between the general morphology of wave-influenced deltas (lobes) and the hydraulics of the river (distributary) mouth that should provide impetus for further refinements.

\section{IMPLICATIONS FOR INTERPRETATION OF SUBSURF ACE DATA}

The mechanism for asymmetric wave-influenced delta formation discussed here suggests an organized and therefore predictable facies architecture that may be used in interpreting ancient systems. Updrift areas are more likely to consist of sheet sandstones representing beach and shoreface deposits relative to their downdrift counterparts. Less mud is associated with the updrift areas, and this should lead to relatively sandy and poten- 
tially sharp-based shoreface deposits. In downdrift areas, progradation produces a series of narrow barrier-shoreface sandstones separated by topographically low areas mostly filled with fine-grained sediments. They could include sediments derived from a bayhead delta with complete channel, mouth bar, delta front and prodelta facies. Palaeocurrent directions and delta front clinoform dips in the bayhead delta facies would be more parallel than normal to the shoreline. Backbarrier lagoons could also fill with floodtidal deltas and storm washovers from the barrier bar. Compactional subsidence of mud may also result in the development of extensive lagoons or lakes downdrift. In contrast to updrift areas, extensive prodelta muds underlie the downdrift regions. Sands deposited downdrift show lower textural maturity than the more highly reworked sands in the updrift areas (e.g. Sao Francisco; Dominguez et al., 1987; Dominguez, 1996). Associated with this myriad of closely linked environments, vertical successions located downdrift of the mouth may show a high degree of interbedding of sandstones and mudstones.

Complexity is expected for the facies architecture of asymmetric wave-influenced delta lobes. Surface studies of modern deltas show that extensive sheet sands are rare and that a single, sandy, upward-coarsening facies succession would probably not be typical of most of these deltas. This is useful to keep in mind when interpreting deltaic successions in ancient strata, especially where based on mapping sandstone thickness, such as is common in subsurface studies (e.g. Weise, 1980; Bhattacharya \& Walker, 1991). From the perspective of hydrocarbon reservoirs, the best quality sands will probably be associated with the updrift side of asymmetrictype wave-influenced deltas (e.g. $\approx 30 \%$ areal extent in the Danube delta). In the case of asymmetric deltas, where the sand bypass is large and fast (e.g. Paraibo do Sul), as well as for symmetric deltas, equally well-developed reservoirs are expected on both sides of the mouth.

There are caveats to the asymmetric model. In smaller deltas such as the Brazos, some of these updrift sediments may have low preservation potential as they are eroded and reworked alongshore after delta abandonment, such as occurred after the diversion of the Brazos river in 1929 (Hamilton \& Anderson, 1994; Hamilton, 1995; Rodriguez et al., 2000). The degree of preservation of delta deposits will depend on relative sea-level change, distributary channel avulsion frequency, subsidence rate and the degree of reworking by waves and tides during marine transgression. In some cases, much of the shallow-water, paralic 'topset' facies of the delta plain is removed or reworked during transgressions (e.g. Boyd \& Penland, 1988; Bhattacharya \& Walker, 1992; Posamentier \& Allen, 1999; Bhattacharya \& Willis, 2001).

Changes in sediment calibre have not been considered in the examples discussed. Presumably, rivers that carry mostly sand and gravel, and lack mud, will generate sandy downdrift deposits that would make good reservoirs. This situation should be common in some high-latitude, steepgradient systems with small drainage areas (Orton \& Reading, 1993).

\section{Application to ancient examples}

Reservoir modellers are becoming increasingly concerned about the details of facies architecture that affect interwell heterogeneities (Tyler \& Finley, 1991; Flint \& Bryant, 1993; Haldorsen \& Damsleth, 1993). The assumption that waveinfluenced deltas make homogeneous reservoirs does not appear to be compatible with the work reviewed in this paper. The process-based model proposed here for the formation of wave-influenced delta systems may help in building subsurface models of these types of reservoirs.

Several sandstones in the Cretaceous Interior Seaway of North America, including the Gallup Sandstones in New Mexico (Fig. 12) and the Almond Sandstone in Wyoming, show a lateral transition from sandy shoreface deposits into muddy lagoonal or distributary plain facies (e.g. McCubbin, 1982). These sandstones were described in the context of 'classic' barrier islands and strandplain depositional systems (McCubbin, 1982), but they could be interpreted as smaller components of larger asymmetric delta systems. In a palaeoeographic map of the Gallup Formation (Fig. 12), reconstructed from subsurface cores and well logs, a wave-formed strandplain is depicted as enclosing a mud-dominated distributary plain that resembles the bayhead delta facies predicted by the asymmetric model. Amalgamated beach facies in the south-east resemble the updrift wing of an asymmetric delta. The 'strandplain' may be better interpreted as a waveformed barrier bar system formed along the downdrift side of a major delta, as the model predicts (Fig. 12).

In a study of the Viking Formation sandstones in Alberta, Canada, MacEachern et al. (1998) re-examined a tide-influenced bayhead delta 


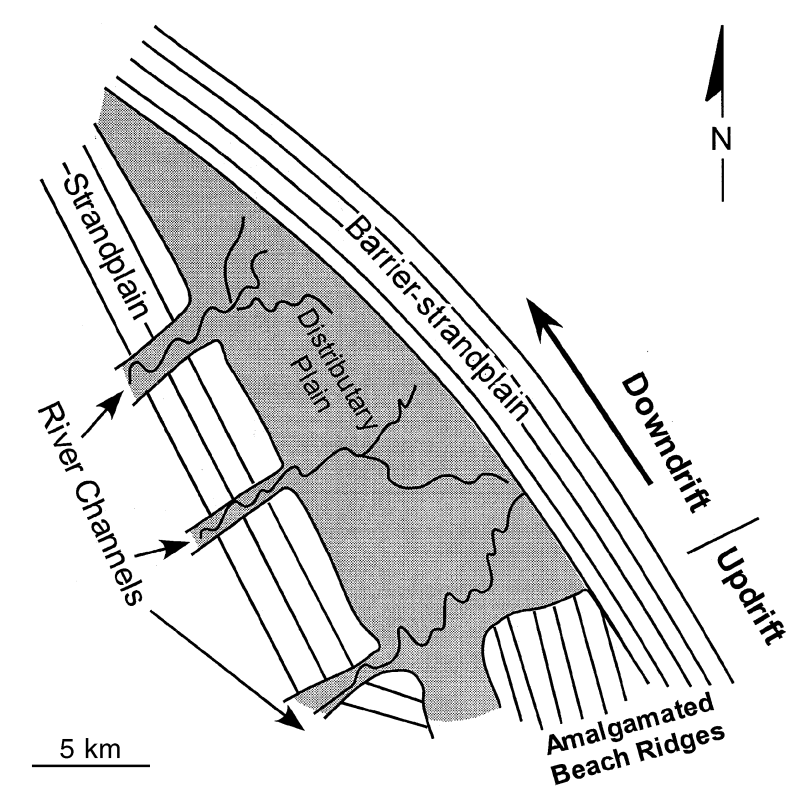

Fig. 12. Gallup Sandstones (New Mexico, USA) interpreted by McCubbin (1982) in the context of 'classic' barrier islands and strandplain depositional systems sandstones. Based on the asymmetric model, the Gallup strandplain may have formed on the updrift side of a large asymmetric wave-influenced delta.

succession, originally interpreted to be formed in an estuarine, incised valley fill. The authors showed that these bayhead delta facies formed within a backbarrier lagoonal bay, enclosed by a sandy barrier island, with a palaeogeography identical to the Gallup example discussed above. This interpretation was made largely on the assumption that estuarine, bayhead delta facies only form in transgressed valleys. MacEachern et al.'s (1998) study reinforces the point that local observation must be placed within a larger basinal context before depositional systems can be fully described and correctly interpreted. It is not unreasonable to assume that this Viking barrier lagoon/bayhead delta complex may have formed on the downdrift margin of a larger asymmetric wave-influenced delta.

In this paper, the term bayhead delta has been used to refer to any river-fed delta deposit that lies at the head of any bay, regardless of the origin or type of bay. The term 'bayhead delta' has recently been used in the rather restrictive context as a component of an incised valley-type estuary (Dalrymple et al., 1992). This is potentially misleading because there are many types of bays (including the lagoons that are described here as well as the Viking example of MacEachern et al., 1998) that are demonstrably not associated with incised valleys. Because the facies associ- ated with bayhead deltas formed in these different environments are practically the same, a restricted use of the term can lead to potentially incorrect interpretations. The critical issue in proposing and using any terminology should be the context in which a facies occurs rather than historical considerations on the use of that terminology.

Many other ancient sandstones have been broadly interpreted as prodelta 'sand plume' deposits or offshore bars, in which longshore drift, storm-induced geostrophic currents or tidal currents carry sands far offshore and rework them into barrier bars (e.g. Palmer \& Scott, 1984; Winn, 1991). These models have recently been challenged with the recognition that sea-level change plays an important role (e.g. Scheihing \& Gaynor, 1991; Walker \& Plint, 1992; Bergman, 1994). Many of these previously interpreted shelf sandbodies are now interpreted as top-truncated lowstand shoreface and delta deposits (e.g. Plint, 1988; Bergman, 1994; Bhattacharya \& Willis, 2001). These ancient systems are logical places to look for the facies asymmetry that is predicted here. The prograding barrier-lagoon systems of units such as the Gallup, Almond and Viking Formations may prove to form components of larger scale asymmetric wave-influenced deltaic depositional systems. Lobate sandbody geometries of the Almond, in particular, suggest a more deltaic origin rather than a barrier island interpretation (McCubbin, 1982).

Weise (1980), in one of the few detailed studies of ancient wave-dominated delta systems, showed asymmetric isopach map patterns (Fig. 13). With the assumption that sand was derived directly from the associated river, and not from along-strike feeders, Weise (1980) inferred that thicker sandier facies were deposited downdrift of the river mouth. The new asymmetric model suggests that these sands may have been preferentially deposited on the updrift side. An alternative interpretation of these deltas as of a deflected type is unlikely given the broad setting on a shallow, extensive highstand shelf. Again, at this stage, these reinterpretations must remain speculative until more detailed work can be done incorporating the concepts outlined in this paper, but the new model is presented as an alternative for future re-examination of ancient systems.

Choosing the facies model for a particular ancient example can be difficult. This is especially true in deltas such as the Danube, which show a tremendous variability in process and facies, both between lobes and within each lobe. 

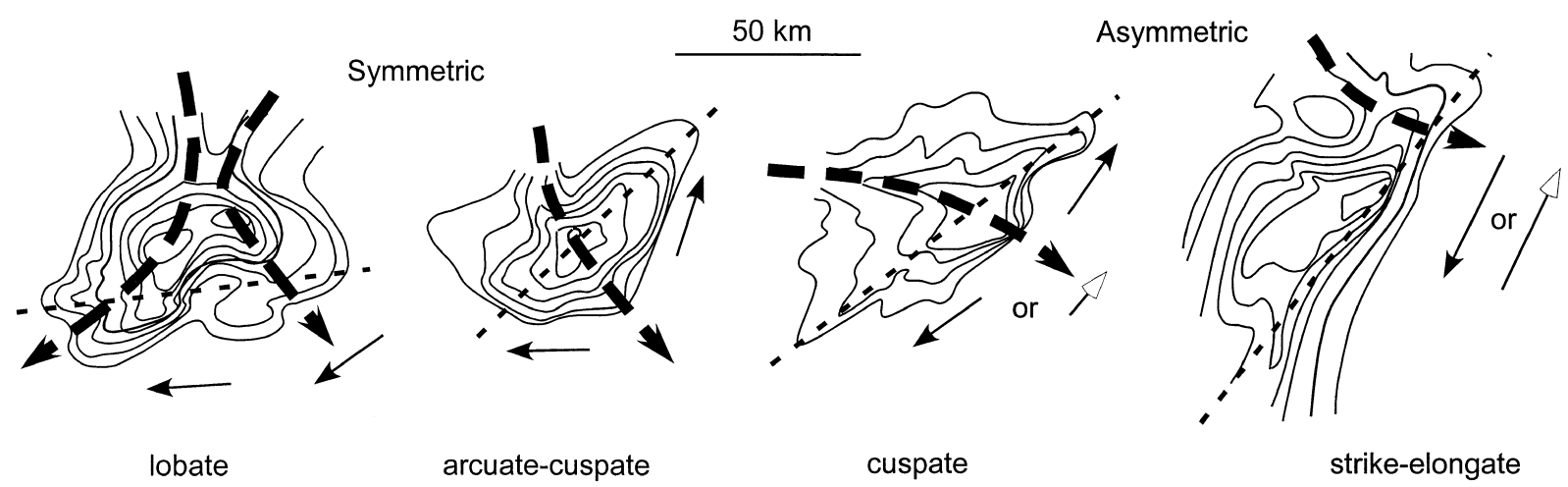

strike-elongate

Fig. 13. Symmetric vs. asymmetric deltas of the Cretaceous San Miguel Formation, Texas (after Weise, 1980). The asymmetric delta model, which predicts that the bulk of sand deposition is on the updrift flank, suggests that the original interpretation of longshore drift directions may be incorrect. The strike direction is represented by the thin dashed line; the direction of riverine sediment input is shown by thick dashed arrows; small black arrows indicate the longshore drift as originally proposed by Weise (1980), whereas the small white arrows indicate the direction of the drift proposed here based on the asymmetric delta model.

Care must be taken in interpreting the facies architecture of ancient deltaic, shoreface and shelf depositional systems, especially in an exploration scenario where few data are usually available. Cores or well logs from one part of a complex system may look very different from those from another area. Specifically, bayhead deltas and barrier islands may form components of large asymmetric prograding deltas systems and do not automatically mean that transgression has occurred. Having stated this, deltas can also change their character through time as a result of changes in sediment supply and sea level (Bhattacharya \& Walker, 1992). With decreasing sediment supply, for example, the Nile delta has become more wave dominated and is transgressing in several areas (Sestini, 1989). The issue of scale cannot be overstressed. The Danube contains delta lobes and channels at a variety of scales from the whole delta to the three main lobes to more localized sublobes at the termination of individual small-scale distributary channels. Wave and river processes operate at all these different scales. Although these scales are obvious in the modern system, distinguishing these scales in an ancient system may be much harder, depending on the quality and amount of data. Significant tides will complicate facies distributions further.

The modern deltas reviewed here suggest that ancient wave-influenced deltas may be distinguished from purely wave-dominated strandplain deposits by the presence of significant riverborne mudstones in the prodelta and, in the case of asymmetric deltas, in downdrift areas. The wave-influenced deltas described here contain a greater proportion of muds than earlier models would suggest. The arrangement and spatial distribution of the mud-dominated lithologies may have important implications for predicting reservoir quality that affect recovery processes. Asymmetry in ancient wave-influenced deltas allows the prediction of persistent palaeo-longshore drift patterns. It may be used as a model to predict and map reservoir quality and to model facies heterogeneity and fluid flow in ancient reservoirs, although more work is required in order to demonstrate that delta asymmetry can be recognized in other ancient systems.

\section{IMPLICATIONS FOR THE DEFINITION OF DELTAS}

The new approach towards wave-influenced deltas shows that longshore drift can contribute sediments in quantities similar to those supplied by an individual delta-forming distributary. This approach suggests that more extensive sheet sandstones should be expected on wave-dominated coasts where net longshore transport is insignificant (i.e. low asymmetry index). Planview models of deltas (Fig. 1) predict the fluvial feeder channel to lie landward of the shoreline (vs. along-strike) forming a simple proximaldistal relationship between delta front and river. In the case of deflected wave-influenced deltas, however, the channel may be oriented parallel to the shoreline. Even in asymmetric deltas, secondary bayhead deltas may be oriented at a low angle to the general shoreline trend. As a consequence, the new model proposed here shows that, 
as longshore transport becomes more important (increasing asymmetry index), the river and associated delta front and shoreface sands do not exhibit a simple proximal-distal relationship.

In the São Francisco delta, about half the sand is derived from the modern river, with the other half being reworked from the shelf (Dominguez, 1996). Based on this, Dominguez (1996) proposed that the São Francisco is a strandplain, not a delta. In contrast, Bhattacharya \& Walker (1992) argued that the São Francisco should be regarded as a delta because: (1) it is a protuberance in the shoreline at a point where a river enters the ocean; (2) it has a broadly lobate shape in plan view with narrowing in the direction of the feeding river; and (3) a significant proportion of the deposit, including all the mud, is derived from the river. This review of wave-influenced deltas shows that the definition adopted by Bhattacharya \& Walker (1992) suits the large spectrum of processes associated with these environments better. The São Francisco delta, like the Danube wave-influenced lobes, clearly belongs in the middle of the spectrum of depositional systems, exhibiting significant fluvial as well as basinal influences.

Well-developed sand sheets may form in symmetric wave-influenced deltas, where most of the sand is of fluvial origin, or in strandplains, where sand is derived from alongshore and/or offshore. Although the formation of mouth bars is favoured by high river discharges, these are readily reworked into beach and shoreface deposits in wave-influenced deltas, making the distinction between wave-formed shorefaces and wavedominated deltas difficult.

Along the modern coast of Nayarit (Curray et al., 1969), some sandy promontories are clearly associated with rivers (e.g. Rio Grande de Santiago; Fig. 14). In strandplains, however, some protuberances may not be evidently associated with a river and may form in areas of convergent longshore transport or may represent erosional features formed by divergences in longshore sediment transport. This may be the case for the promontory located south-west of Laguna Agua Brava, which is not obviously associated with a river and appears to occur at the convergence points of the longshore drift (Fig. 14). This area comprises an extensive sheet of amalgamated beach and shoreface ridges about $15 \mathrm{~km}$ wide (normal to the shoreline) and about $50 \mathrm{~km}$ in length (parallel to the shoreline). A similar depositional promontory has been described in the Caravelas strandplain on the Brazilian coast (Dominguez et al., 1987). The Nayarit coast has long been cited as the type example of a nondeltaic prograding wave-dominated strandplain (e.g. McCubbin, 1982; Walker \& Plint, 1992). However, it is worth noting that Curray et al. (1969) originally pointed out: 'The Nayarit coastal plain is an example of a type of deltaic coast

\section{Coast of Nayarit, Mexico}

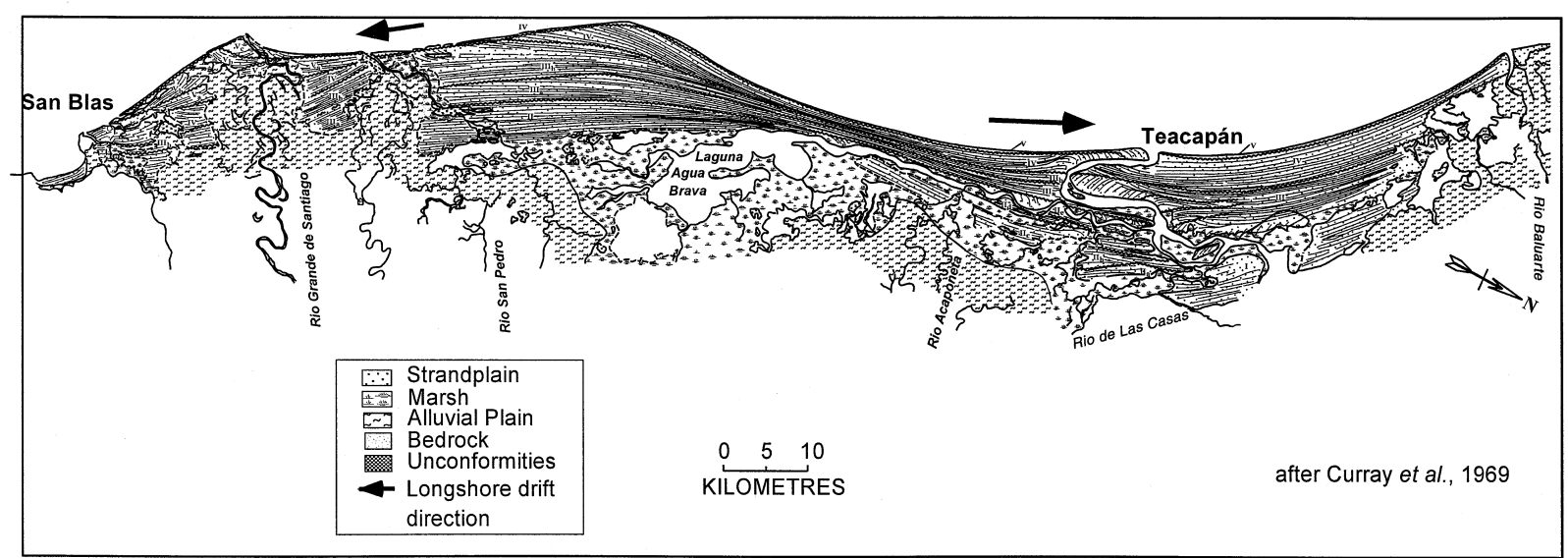

Fig. 14. Coast of Nayarit (Mexico) interpreted as a prograding wave-dominated coastal strandplain with deltaic promontories (after Curray et al., 1969). This type of sedimentary environment would tend to produce relatively homogeneous sheet sandstones, although some river-derived mudstone could be deposited near the mouths of the principal rivers (e.g. Rio Grande de Santiago). Note the diverging longshore drift directions. Changes in longshore drift direction cause changes in beach ridge orientation and produce unconformities visible on the surface. Various beach ridge plain complexes have been dated, and their relative ages are shown with roman numerals where I is the oldest and $\mathrm{V}_{\mathrm{c}}$ is the youngest. 
which is especially important in the geologic record. While large rivers and deltas must have existed throughout geologic time, perhaps the smaller, coalesced deltaic coastal plains, such as Nayarit, were also of very great importance'.

The Coast of Nayarit should thus be reconsidered as a combined deltaic-strandplain system that shows localized river influence. Predicting the location of associated fluvial and distributary channel facies in ancient analogues may be more difficult in such cases, although the river influence is usually well recorded in the biofacies. Specific features that may indicate fluvial influence include decreased proportions of planktonic microfauna (e.g. foraminifera), an increase in the proportion of land-derived material (e.g. increase in spores and pollen), a decrease in filter-feeding organisms and a decrease in diversity and abundance of trace fossils (Moslow \& Pemberton, 1988; Bhattacharya \& Walker, 1992; Pemberton \& Wightman, 1992; Gingras et al., 1998). Also, direct sedimentological evidence for high sedimentation rates or high sediment concentrations, such as abundant climbing current ripples, can indicate river influence (Bhattacharya \& Walker, 1992).

\section{CONCLUSIONS}

A survey of modern examples shows that waveinfluenced deltas exhibit a variable degree of asymmetry in morphology and facies. An asymmetry index, $A$, defined as the ratio between longshore transport rate $\left(\mathrm{m}^{3}\right.$ year $\left.^{-1}\right)$ and river discharge ( $Q$ in $10^{6} \mathrm{~m}^{3} \mathrm{month}^{-1}$ ), was devised to explore the marine-fluvial interaction at the mouth of a deltaic distributary (Table 1, Fig. 11). Published data show that asymmetry is favoured in deltas with an index over $\approx 200$. An extreme case of asymmetry is that of deflected deltas (e.g. Mahanadi, Senegal) where the river may periodically be deflected considerable distances downdrift.

A facies model for asymmetric deltas predicts significant river-borne muds with potentially lower quality reservoir facies in prodelta and downdrift areas and better quality sand in updrift areas. If the model is confirmed in further tests, many ancient barrier-lagoon systems and 'offshore bars' could be reinterpreted as components of large-scale asymmetric wave-influenced deltaic systems.

More generally, there is a complete spectrum from strandplain systems with minor deltaic promontories to river-dominated deltas with minor wave reworking. The definition for deltas should therefore be relaxed to include sediment delivered via longshore/onshore basinal transport but in which deposition is caused by the groyne effect at a distributary channel mouth.

Many deltas show river-, wave- and tide-dominated facies both between and within lobes, but in variable proportions. Bayhead deltas and barrier islands naturally form in prograding asymmetric deltas and do not necessarily require interpretation as being associated with a transgressive system, such as an estuarine incised valley fill. With limited data, a common situation in petroleum exploration, simplified classification schemes based on relative importance of fluvial vs. marine processes based on the present ternary classification of deltas can be misleading. Depositional systems may be misinterpreted if not placed into a larger palaeogeographic context. This may lead to erroneous estimations of facies architecture, reservoir distribution and reservoir quality. The asymmetric model is a significant step in quantifying the fluvial-basinal interaction in modern systems that could lead to better facies distribution predictions in ancient systems.

\section{ACKNOWLEDGEMENTS}

Funding for this research was provided by BP, Chevron and the American Chemical Society, ACS-PRF grant no. 35855-AC8 to J. P. Bhattacharya, and by CICOR (a Joint Institute of Woods Hole Oceanographic Institution and NOAA) to L. Giosan, whom we thank. Earlier ideas in this manuscript were fruitfully discussed with John Bridge, Henry Bokuniewicz, Roger Flood and Daniel Conley. L. Giosan thanks M. Rucareanu (University of Montreal) for discussion on the GPR structure of the Sãaaturile Formation. We benefited from reviews by Sedimentology's editor Chris Fielding, Bill Galloway and an anonymous reviewer. The reviewers noted several points of potential confusion, and their suggestions resulted in what we hope is a more comprehensive and more clearly illustrated paper. Naturally, any shortfalls in interpretation or communication remain our own. This is contribution number 965 of the Geosciences Department, University of Texas at Dallas, and contribution number 10646 of the Woods Hole Oceanographic Institution. 


\section{REFERENCES}

Ausseil-Badie, J., Barusseau, J.P., Descamps, C., Diop, E.H.S., Giresse, P. and Pazdur, M.F. (1991) Holocene deltaic sequence in the Saloum Estuary, Senegal. Quatern. Res., 36, 178-194.

Banu, A.C. and Rudescu, L. (1965) Delta Dunarii. Editura Stiintifica, Bucuresti, 295 pp.

Barusseau, J.P., Ba, M., Descamps, C., Diop, E.H.S., Giresse, P. and Saos, J.-L. (1995) Coastal evolution in Senegal and Mauritania at $10^{3}, 10^{2}$ and 10-year scales; natural and human records. Quatern. Int., 29-30, 61-75.

Bellotti, P., Chiocci, F.L., Milli, S. and Tortora, P. (1993) Variabilita nel tempo della distribuzione granulometrica sui fondali del Delta del Tevere. Boll. Soc. Geol. Ital., 112, 143153.

Bellotti, P., Chiocci, F.L., Milli, S., Tortora, P. and Valeri, P. (1994) Sequence stratigraphy and depositional setting of the Tiber Delta; integration of high-resolution seismics, well logs, and archeological data. J. Sed. Res., 64, 416-432.

Benninger, L.K., Suayah, I.B. and Stanley, D.J. (1998) Manzala lagoon, Nile delta, Egypt: modern sediment accumulation based on radioactive tracers. Environ. Geol., 34, 183-193.

Bergman, K.M. (1994) Shannon sandstone in Hartzog DrawHeldt Draw fields reinterpreted as detached lowstand shoreface deposits. J. Sed. Res., B64, 184-201.

Bharali, B., Rath, S. and Sarma, R. (1991) A brief review of Mahanadi Delta and the deltaic sediments in Mahanadi Basin. In: Quaternary Deltas of India (Ed. R. Vaidyanadhan), Mem. Geol. Soc. India, 22, 31-49.

Bhattacharya, J. and Walker, R.G. (1991) Facies and facies successions in river- and wave-dominated depositional systems of the Upper Cretaceous Dunvegan Formation, northwestern Alberta. Bull. Can. Petrol. Geol., 39, 165-191.

Bhattacharya, J.P. and Walker, R.G. (1992) Deltas. In: Facies Models: Response to Sea-Level Change (Eds R.G. Walker and N.P. James), pp. 157-177. Geological Association of Canada, St Johns.

Bhattacharya, J.P. and Willis, B.J. (2001) Lowstand deltas in the Frontier Formation, Powder River basin, Wyoming: implications for sequence stratigraphic models. AAPG Bull., 85, 261-294.

Bondar, C., State, I., Cernea, D. and Harabagiu, E. (1992) Scurgerea de apa si aluviuni a Dunarii la gurile bratelor Dunarii in anii 1858-1988. Stud. Hidraul., XXXIII, 57-71.

Bortoluzzi, G., Frascari, F., Guerzoni, S., Incremona, N., Ravaioli, M. and Rovatti, G. (1982) Some sedimentological and chemical features of the seafloor in front of the Tiber River. Geogr. Fis. Din. Quatern., 5, 120-128.

Boyd, R. and Penland. S. (1988) A geomorphic model for Mississippi delta evolution. Trans. Gulf Coast Assoc. Geol. Soc., 38, 443-452.

Broussard, M.L. (ed.) (1975) Deltas, Models for Exploration. Houston Geological Society, Houston, TX, 555 pp.

Bruun, P. and Gerritsen, F. (1959) Natural by-passing of sand at coastal inlets. Proc. Am. Soc. Civ. Eng., 85, 75-107.

Chen, Z., Warne, A.G. and Stanley, D.J. (1992) Late Quaternary evolution of the northwestern Nile Delta between the Rosetta Promontory and Alexandria, Egypt. J. Coastal Res., 8, 527-561.

Collela, A. and Prior, D.B. (eds) (1990) Coarse-grained deltas. Int. Assoc. Sedimentol. Spec. Publ., 10, 357 pp.

Coleman, J.M. and Wright, L.D. (1975) Modern river deltas. variability of processes and sand bodies. In: Deltas, Models for Exploration (Ed. M.L. Broussard), pp. 99-149. Houston Geological Society, Houston, TX.

Corner, G.D., Nordahl, E., Munch-Ellingsen, K. and Robertson, K.R. (1990) Morphology and sedimentology of an emergent fjord-head Gilbert-type delta: Alta delta, Norway. In: Coarse Grained Deltas (Eds A. Collela and D.B. Prior), Int. Assoc. Sedimentol. Spec. Publ., 10, 155-168.

Coutellier, V. and Stanley, D.J. (1987) Late Quaternary stratigraphy and palaeogeography of the eastern Nile Delta, Egypt. Mar. Geol., 77, 257-275.

Curray, J.R., Emmel, F.J. and Crampton, P.J.S. (1969) Holocene history of a strand plain, lagoonal coast, Nayarit, Mexico. In: Coastal Lagoons, a Symposium (Eds A.A. Castañares and F.B. Phleger), pp. 63-100. University Nacional Autonoma Mexico-UNESCO, Mexico.

Dalrymple, R.W., Zaitlin, B.A. and Boyd, R. (1992) Estuarine facies models; conceptual basis and stratigraphic implications. J. Sed. Petrol., 62, 1130-1146.

Diaconu, C. and Nichiforov, I.D. (1963) Zona de Varsare a Dunarii. Editura Tehnica, Bucuresti, 396 pp.

Dominguez, J.M.L. (1996) The São Francisco strandplain: a paradigm for wave-dominated deltas?. In: Geology of Siliciclastic Shelf Seas (Eds M. De Baptist and P. Jacobs), Geol. Soc. London Spec. Publ., 117, 217-231.

Dominguez, J.M.L., Bittencourt, A.C.S.P. and Martin, L. (1983) O papel da deriva litoranea de sedimentos arenosos na construcao das planicies costeiras associadas as desembocaduras dos rios Sao Francisco, Jequitinhonha, Doce e Paraiba do Sul. Rev. Brasil. Geocienc., 13, 98-105.

Dominguez, J.M.L., Martin, L. and Bittencourt, A.C.S.P. (1987) Sea-level history and Quaternary evolution of river mouthassociated beach-ridge plains along the east-southeast Brazilian coast: a summary. In: Sea-Level Fluctuations and Coastal Evolution (Eds D. Nummedal, O.H. Pilkey and J.D. Howard), SEPM Spec. Publ., 41, 115-127.

El-Askary, M.A. and Lofty, M.F. (1980) Depositional environment of the islands in Manzala lake, Egypt, deduced by grain size analysis. Bull. Fac. Sci. (KAU) - Cairo Univ., 4, 241-255.

Fanos, A.M., Frihy, O.E., Khafagy, A.A. and Komar, P.D. (1991) Processes of shoreline changes along the Nile delta coast of Egypt. In: Coastal Sediments '91 (Eds N.C. Kraus, K.J. Gingerich and D.L. Kriebel), pp. 1547-1557. Am. Soc. Civ. Eng., New York.

Fanos, A.M., Khafagy, A.A. and Komar, P.D. (1993) Erosion of the Damietta Promontory, the Nile Delta. In: Coastal Engineering '92 (Ed. W.L. Edge), pp. 3246-3259. Am. Soc. Civ. Eng., New York.

Fanos, A.M., Khafagy, A.A. and Komar, P.D. (1995) Long and short term changes of Rosetta Promontory, Egypt. In: MEDCOAST 95 (Ed. E. Ozhan), pp. 1033-1046. MEDCOAST, Ankara, Turkey.

Fisher, W.L., Brown, L.F., Scott, A.J. and McGowen, J.H. (1969) Delta Systems in the Exploration for Oil and Gas, a Research Colloquium. Bur. Econ. Geol., Univ. Texas, Austin, $204 \mathrm{pp}$.

FitzGerald, D.M. (1982) Sediment bypassing at mixed energy tidal inlets. Proceedings 18th Coastal Engineering Conference (Ed. W.L. Edge), pp. 1094-1118. Am. Soc. Civ. Eng., New York.

FitzGerald, D.M. (1988) Shoreline erosional-depositional processes associated with tidal inlets. In: Hydrodynamics and Sediment Dynamics of Tidal Inlets (Eds D.G. Aubrey and L. Weishar), Lecture Notes Coastal and Estuarine Studies, 29, pp. 186-225. Springer-Verlag, New York. 
Flint, S.S. and Bryant, I.D., eds. (1993) The geological modeling of hydrocarbon reservoirs and outcrop analogues. Int. Assoc. Sedimentol. Spec. Publ., 15, 269 pp.

Galloway, W.E. (1975) Process framework for describing the morphologic and stratigraphic evolution of deltaic depositional systems. In: Deltas, Models for Exploration (Ed. M.L. Broussard), pp. 87-98. Houston Geological Society, Houston, TX.

Galloway, W.E. and Hobday, D.K. (1996) Terrigenous Clastic Depositional Systems. Springer-Verlag, Heidelberg, 489 pp.

Gastescu, P. (1992) Danube Delta - Tourist Map. Editura Sport-Turism, Bucuresti.

Gingras, M.K., MacEachern, J.A. and Pemberton, S.G. (1998) A comparative analysis of the ichnology of wave- and riverdominated allomembers of the Upper Cretaceous Dunvegan Formation. Bull. Can. Petrol. Geol., 46, 51-73.

Giosan, L. (1993) Studiul Evolutiei Dinamice a Sedimentelor in Zona Litorala din fata Deltei Dunarii. Unpubl. Dipl. Thesis, Bucharest University, 75 pp.

Giosan, L. (1998) Long term sediment dynamics on Danube delta coast. In: Physics of Estuaries and Coastal Seas (Eds J. Dronkers and M. Scheffers), pp. 365-376. Balkema, Rotterdam.

Giosan, L., Bokuniewicz, H., Panin, N. and Postolache, I. (1999) Longshore sediment transport pattern along the Romanian Danube delta coast. J. Coastal Res., 15, 859-871.

Haldorsen, H.H. and Damsleth, E. (1993) Challenges in reservoir characterization. AAPG Bull., 77, 541-551.

Hamilton, M.D. (1995) Detailed Facies Analysis of the Brazos Wave-dominated Delta, Freeport, Texas. Unpubl. MSc Thesis, Rice University, Houston, TX, 206 pp.

Hamilton, M.D. and Anderson, J.B. (1994) Facies architecture and evolution of the Brazos Delta, Houston, Texas. Rice University, unpubl. guidebook, $26 \mathrm{pp}$.

Hayes, M.O. (1979) Barrier island morphology as a function of tidal and wave regime. In: Barrier Islands from the Gulf of St. Lawrence to the Gulf of Mexico (Ed. S.P. Leatherman), pp. 1-27. Academic Press, New York.

l'Homer, A., Bazile, F., Thommeret, J. and Thommeret, Y. (1981) Principales étapes de l'édification du delta du Rhone de 7000BP à nos jours, variations du niveau marin. Oceanis, 7, 389-408.

Jimenez, J.A. and Sanchez-Arcilla, A. (1993) Medium-term coastal response at the Ebro Delta, Spain. Mar. Geol., 114, 105-118.

Komar, P.D. (1973) Computer models of delta growth due to sediment input from rivers and longshore transport. Geol. Soc. Am. Bull., 84, 2217-2226.

McCubbin, D.G. (1982) Barrier-island and strand-plain facies. In: Sandstone Depositional Environments (Eds P.A. Scholle and D.R. Spearing), AAPG Mem., 31, 247-280.

MacEachern, J.A., Zaitlin, B.A. and Pemberton, S.G. (1998) High-resolution sequence stratigraphy of early transgressive deposits, Viking Formation, Joffre Field, Alberta, Canada. AAPG Bull., 82, 729-755.

Maldonado, A. (1975) Sedimentation, stratigraphy, and development of the Ebro Delta, Spain. In: Deltas, Models for Exploration (Ed. M.L. Broussard), pp. 311-338. Houston Geological Society, Houston, TX.

Martin, L., Suguio, K., Flexor, J.-M., Dominguez and Bittencourt, A.C.D.S. (1987) Quaternary evolution of the central part of the Brazilian coast; the role of relative sea-level variation and of shoreline drift, Quaternary coastal geology of West Africa and South America. UNESCO Techn. Papers Mar. Sci., 43, 97-145.
Meijerink, A.M.J. (1982) Dynamic geomorphology of the Mahanadi delta. ITC J., 3, 243-250.

Miall, A.D. (1979) Deltas. In: Facies Models (Ed. R.G. Walker), Geosci. Canada Reprint Series, 1, 43-56.

Michel, P. (1968) Genese et evolution de la vallee du Senegal, de Bakel a l'embouchure (Afrique occidentale). Z. Geomorphol., 12, 319-349.

Mohanti, M. (1993) Coastal processes and management of the Mahanadi River deltaic complex, east coast of India. In: Deltas of the World (Ed. R. Kay), pp. 122-136. Am. Soc. Civ. Eng., New York.

Morales, J.A. (1997) Evolution and facies architecture of the mesotidal Guadiana River delta (SW Spain-Portugal). Mar. Geol., 138, 127-148.

Moslow, T.F. and Pemberton, S.G. (1988) An integrated approach to the sedimentological analysis of some lower Cretaceous shoreface and delta front sandstone sequences. In. Sequences, Stratigraphy, Sedimentology; Surface and Subsurface (Eds D.P. James and D.A. Leckie), Can. Soc. Petrol. Geol. Mem., 15, 373-386.

Noakes, J.E. and Herz, N. (1983) University of Georgia radiocarbon dates VII. Radiocarbon, 25, 919-929.

Odem, W.I. (1953) The Delta of the Diverted Brazos River of Texas. Unpubl. MSc Thesis, University of Kansas.

Oomkens, E. (1970) Depositional sequences and sand distribution in the postglacial Rhone delta complex. In: Deltaic Sedimentation Modern and Ancient (Ed. J.P. Morgan), SEPM Spec. Publ., 15, 198-212.

Orton, G.J. and Reading, H.G. (1993) Variability of deltaic processes in terms of sediment supply, with particular emphasis on grain size. Sedimentology, 40, 475-512.

Palmer, J.J. and Scott, A.J. (1984) Stacked shoreline and shelf sandstones of the La Ventana Tongue (Campanian), Northwestern New Mexico. AAPG Bull., 68, 74-91.

Panin, N. (1989) Danube Delta: genesis, evolution and sedimentology. Rev. Roum. Géol., 33, 25-36.

Panin, N. (1997) On the geomorphologic and geologic evolution of the River Danube-Black Sea interaction zone. GeoEco-Marina, 2, 25-30.

Pemberton, S.G. and Wightman, D.M. (1992) Ichnological characteristics of brackish water deposits. In: Applications of Ichnology to Petroleum Exploration (Ed. S.G. Pemberton), SEPM Core Workshop, 17, 141-167.

Plint, A.G. (1988) Sharp-based shoreface sequences and 'offshore bars' in the Cardium Formation of Alberta: their relationship to relative changes in sea level. In: Sea-Level Changes: an Integrated Approach (Eds C.K. Wilgus, B.S. Hastings, C.G.StC. Kendall, H.W. Posamentier, C.A. Ross and J.C. Van Wagoner), SEPM Spec. Publ., 42, 357-370.

Posamentier, H.W. and Allen, G.P. (1999) Siliciclastic Sequence Stratigraphy - Concepts and Applications. SEPM Concepts in Sedimentology and Palaeontology, 7, 216 pp.

Rao, M.S. and Vaidyanadhan, R. (1979) New coastal landforms at the confluence of Godavari River. Ind. J. Geol., 6, 220-227.

Reading, H.G. and Collinson, J.D. (1996) Clastic Coasts. In: Sedimentary Environments: Processes, Facies and Stratigraphy (Ed. H.G. Reading), 3rd edn, pp. 154-231. Blackwell Science, Oxford.

Rodriguez, A.B., Hamilton, M.D. and Anderson, J.B. (2000) Facies and evolution of the modern Brazos Delta, Texas; wave versus flood influence. J. Sed. Res., 70, 283-295.

Romanian Center for Marine Geology and Geoecology (1994) Monitoringul Geo-Ecologic al Sistemului Dunare-DeltaLitoral-Marea Neagra. Centrul Roman de Geologie and Geoecologie Marina, Bucuresti, 46 pp. 
Scheihing, M.H. and Gaynor, G.C. (1991) The shelf sandplume model; a critique. Sedimentology, 38, 433-444.

Seelig, W.N. and Sorensen, R.M. (1973) Investigation of Shoreline Changes at Sargent Beach, Texas. Coastal and Ocean Engineering Division Report, 169. Texas A\&M University, $153 \mathrm{pp}$.

Sestini, G. (1989) Nile delta: a review of depositional environments and geological history. In: Deltas: Sites and Traps for Fossil Fuel (Eds M.K.G. Whateley and K.T. Pickering), Geol. Soc. London Spec. Publ., 41, 99-127.

Sneh, A. and Weissbrod, T. (1973) Nile delta; the defunct Pelusiac branch identified. Science, 180, 59-61.

Stanley, D.J. and Warne, A.G. (1998) Nile delta in its destruction phase. J. Coastal Res., 14, 794-825.

Suter, J.R. (1994) Deltaic coasts. In: Coastal Evolution; Late Quaternary Shoreline Morphodynamics (Eds R.W.G. Carter and C.D. Woodroffe), pp. 87-120. Cambridge University Press, Cambridge.

Todd, T.W. (1968) Dynamic diversion: influence of longshore current-tidal flow interaction on chenier and barrier island plains. J. Sed. Petrol., 38, 734-746.

Tyler, N. and Finley, R.J. (1991) Architectural controls on the recovery of hydrocarbons from sandstone reservoirs. In: The Three-Dimensional Facies Architecture of Terrigenous Clastic Sediments, and its Implications for Hydrocarbon Discovery and Recovery (Eds A.D. Miall and N. Tyler), SEPM Concepts Models Sedimentol. Palaeontol., 3, 1-5.

US Army Corps of Engineers (1995) Coastal Inlet Hydraulics and Sedimentation, Engineer Manual. US Army Corps of Engineers, Vicksburg, 137 pp.

Vaidyanadhan, R. and Rao, M.S. (1979) Morphology and evolution of Godavari Delta, India. Z. Geomorphol., 23, 243255.
Vespremeanu, E. (1983) Geomorphological evolution of Sfintu Gheorghe arm mouth (Danube delta, North-West of the Black Sea) in the last 200 years. Rev. Roum. Géol., 27, 61-68.

Walker, R.G. and Plint, A.G. (1992) Wave- and storm-dominated shallow marine systems. In: Facies Models: Response to Sea-Level Change (Eds R.G. Walker and N.P. James), pp. 219-238. Geological Association of Canada, St Johns.

Weise, B.R. (1980) Wave-dominated deltaic systems of the Upper Cretaceous San Miguel Formation, Maverick Basin, South Texas. Bur. Econ. Geol. Univ. Tex. Austin Rep. Inv., 107, 39 pp.

Willis, B.J., Bhattacharya, J.B., Gabel, S.L. and White, C.D. (1999) Architecture of a tide-influenced delta in the Frontier Formation of Central Wyoming, USA. Sedimentology, 46, 667-688.

Winn, R.D. (1991) Storm deposition in marine sand sheets: Wall Creek Member, Frontier Formation, Powder River Basin, Wyoming. J. Sed. Petrol., 61, 86-101.

Wright, L.D. (1977) Sediment transport and deposition at river mouths: a synthesis. Geol. Soc. Am. Bull., 88, 857-868.

Wright, L.D. (1985) River deltas. In: Coastal Sedimentary Environments (Ed. A.R. Davis), pp. 1-76. Springer-Verlag, New York.

Wright, L.D. and Coleman, J.M. (1972) River delta morphology; wave climate and the role of the subaqueous profile. Science, 176, 282-284.

Wright, L.D. and Coleman, J.M. (1973) Variations in morphology of major river deltas as functions of ocean wave and river discharge regimes. AAPG Bull., 57, 370-398.

Manuscript received 12 June 2001; revision accepted 15 October 2002. 